\title{
ИЗОТОПНЫЙ СОСТАВ, ПРИРОДА И ОСНОВНЫЕ МЕХАНИЗМЫ ФОРМИРОВАНИЯ СОЛЕНЫХ ОЗЕР ЗАБАЙКАЛЬЯ
}

Борзенко С. В., Замана Л. В., Посохов В. Ф.

\begin{abstract}
Аннотация
На территории Забайкалья изучено более сотни озер, а также подземных вод, рек, атмосферных осадков их водосборов. Проанализирован химический состав природных вод и минеральный состав горных пород и донных отложений озер. Определен изотопный состав вод и изотопные соотношения растворенных и осажденных в донные осадки озер карбонатов и бактериальных матов, а также тяжелого кислорода алюмосиликатной фракции донных отложений и горных пород водосборных территорий. Показано что все вторичные минералы по кислороду наследуют изотопный состав воды, но их кислород существенно тяжелее кислорода воды, т.к. при взаимодействии ее с породой происходит фракционирование кислорода с переходом тяжелого изотопа во вторичные карбонатные и алюмосиликатные образования. Изотопно-тяжелее по кислороду и бактериальные маты, использующие для своей жизнедеятельности кислород углекислотных ионов. Установлено, что вода содовых озер при меньшей ее солености в большей степени обогащена тяжелым изотопом кислорода. Проведены термодинамические расчеты, подтверждающие возможность формирования хемогенных карбонатов и вторичных алюмосиликатов в озерах, определенных минеральным анализом донных осадков и образований из седиментационных ловушек. Показано, что озерная вода находится в равновесии не только с карбонатами, глинами и гидрослюдой, но также с цеолитами, а наиболее щелочные и минерализованные с альбитом. Установлено, что в общей массе минералов донные осадки содовых озер имеют большую долю глин и карбонатов, чем пресные, соленые хлоридные и сульфатные. Представлено, что обогащение вод соленых озер тяжелыми изотопами обязано не только процессу испарения, но и взаимодействию воды с горной породой. Участие реакций гидролиза алюмосиликатов во фракционировании кислорода подтверждается прямой зависимостью величины «кислородного сдвига» от $\mathrm{pH}$, значение которого определяется степенью такого взаимодействия. Установлено, что природа разнообразия химического и изотопного состава озерных вод связана с многофакторным процессом их формирования, обусловленного неодинаковой степенью испарения воды в озерах и разной продолжительностью взаимодействия озерных и подземных вод с горными породами.
\end{abstract}

\section{Ключевые слова:}

Соленые озера, испарение 


\title{
ИЗОТОПНЫЙ СОСТАВ, ПРИРОДА И ОСНОВНЫЕ МЕХАНИЗМЫ ФОРМИРОВАНИЯ РАЗНЫХ ТИПОВ И ПОДТИПОВ СОЛЕНЫХ ОЗЕР ЗАБАЙКАЛЬЯ
}

\author{
С.В. Борзенко ${ }^{1 *}$, Л.В. Замана ${ }^{1}$, В.Ф. Посохов ${ }^{2}$
}

\begin{abstract}
${ }^{1}$ Институт природных ресурсов, экологии и криологии Сибирского отделения Российской академии наук, 672002, Россия, Чита, Недорезова 16a, svb_64@mail.ru and l.v.zamana@mail.ru

${ }^{2}$ Геологический институт Сибирского отделения Российской академии наук, 670047, Россия, Улан-Удэ, Сахьянова 6а vitaf1@yandex.ru
\end{abstract}

\begin{abstract}
АННОТАЦИЯ
На территории Забайкалья изучено более сотни озер, а также подземных вод, рек, атмосферных осадков их водосборов. Проанализирован химический состав природных вод и минеральный состав горных пород и донных осадков озер. Определен изотопный состав вод и изотопные соотношения растворенных и осажденных в донные осадки озер карбонатов и бактериальных матов, а также тяжелого кислорода алюмосиликатной фракции донных отложений и горных пород водосборных территорий. Показано что все вторичные минералы по кислороду наследуют изотопный состав воды, но их кислород существенно тяжелее кислорода воды, т.к. при взаимодействии ее с породой происходит фракционирование кислорода с переходом тяжелого изотопа во вторичные карбонатные и алюмосиликатные образования. Изотопно-тяжелее по кислороду и бактериальные маты, использующие для своей жизнедеятельности кислород углекислотных ионов. Установлено, что вода содовых озер при меньшей ее солености в большей степени обогащена тяжелым изотопом кислорода. Проведены термодинамические расчеты, подтверждающие возможность формирования хемогенных карбонатов и вторичных алюмосиликатов в озерах, определенных минеральным анализом донных осадков и образований из седиментационных ловушек. Показано, что озерная вода находится в равновесии не только с карбонатами, глинами и гидрослюдой, но также с цеолитами, а наиболее щелочные и минерализованные с альбитом. Установлено, что в общей массе минералов донные осадки содовых озер имеют большую долю глин и карбонатов, чем
\end{abstract}


пресные, соленые хлоридные и сульфатные. Представлено, что обогащение вод соленых озер тяжелыми изотопами обязано не только процессу испарения, но и взаимодействию воды с горной породой. Участие реакций гидролиза алюмосиликатов во фракционировании кислорода подтверждается прямой зависимостью величины «кислородного сдвига» от $\mathrm{pH}$, значение которого определяется степенью такого взаимодействия. Установлено, что природа разнообразия химического и изотопного состава озерных вод связана с многофакторным процессом их формирования, обусловленного неодинаковой степенью испарения воды в озерах, минерализацией органического вещества и разной продолжительностью взаимодействия озерных и подземных вод с горными породами.

Ключевые слова

Соленые озера, испарение, взаимодействие воды с горной породой, геохимические типы озер

\section{ВВЕДЕНИЕ}

Огромное влияние на разделение изотопов в гидрологическом цикле гидросферы оказывают испарительные процессы и процессы взаимодействия в системе вода - горная порода - органическое вещество - газ [Northrop and Clayton, 1966; Savin and Epstein, 1970a; Kloppmann et al., 2002; Ga'zquez et al., 2017 Sofer, 1975; Appelo and Postma, 1993; Seal and Shanks, 1998; Gammons et al., 2006; Pellicori et al., 2005; Brooks et al., 2014 и др. и др.]. Трансформация количественного состава изотопов и их соотношения служит естественной меткой, позволяющей судить о степени того или иного процесса. Фракционирование изотопов воды при ее испарении определяется преимущественно кинетическим изотопическим эффектом и изотопным обменом между жидкостью и паром атмосферной влаги [Craig, 1961; Dansgaard, 1964; Good et al., 2014; Gammons et al., 2006; Gibson and Reid, 2014; Sánchez-España et al., 2014 и др.]. Реакции изотопного обмена лежат и в основе процессов взаимодействия воды с горной породой и газом [Clark and Fritz, 1997; Aquilina et al., 1997; Hesse et al., 2000 и др.].

Наиболее полно теоретические и прикладные аспекты гидроизотопных исследований освещены в работах [Craig, 1961; Ферронский и Поляков, 2009; Holland and Turekian, 2011 и др.]. По изотопии водорода и кислорода природных вод Забайкалья самые многочисленные определения до недавнего времени ограничивались данными по оз. 
Байкал и его водосбору [Seal and Shanks, 1998; Plyusnin et al., 2008; Намсараев и др., 2011]. В последние годы нами в Восточном Забайкалье изучается изотопный состав вод в разных ее фазовых состояниях, сульфидной и сульфатной серы [Замана и др., 2010, Замана, 2014], имеются единичные публикации по изотопам воды соленых озер, включая изотопный состав бактериальных обрастаний и карбонатных осадков [Солоноватые..., 2009; Борзенко, 2019]. В этих работах были предприняты первые попытки объединить разрозненные данные и разобраться в биохимических процессах, протекающих в водоемах. Однако вопросы формирования различного состава озер остались за рамками этих исследований. Вместе с тем, информация об изотопном составе озер это ключ к пониманию их генезиса, поскольку природа формирования их разного состава, в особенности содовых, в настоящее время остается спорной [Страхов, 1960; Hardie and Eugster, 1970; Harvie et al.,1980; Drever, 2005; Сонненфельд, 1998; Zheng, 2014; Kolpakova et al., 2019; и др.].

Многими исследователями природа разного состава соленых озер объясняется последовательным испарительным концентрированием вод по мере осаждения сначала наименее растворимых карбонатов Са и Mg, далее сульфатов и т.д. [Вант Гофф, 1936; Курнаков, 1936; Валяшко, 1952; Посохов, 1969; Warren 1989 и др.]. Однако до сих пор нет однозначного объяснения, почему на относительно небольшой территории в близких климатических и ландшафтно-геоморфологических условиях формируются различные типы и подтипы озер: пресные, кислые, соленые содовые, сульфатные и хлоридные. Все эти особенности их состава и особенно содовых озер невозможно объяснить только процессами испарительного концентрирования. Между тем, вне поля зрения исследователей остается роль горных пород, непрерывное растворение которых приводит к созданию новых минеральных образований и геохимических типов воды [Helgeson, 1968; Shvartsev, 1991, 2000 и др., Paćes, 1983; Nordstrom et al., 1989; Kharaka et al., 1990; Drever, 2005; Merkel, 2005; Scislewski and Zuddas, 2010 и др.]. Такой источник химических элементов и соответственно изотопов как горная порода применительно к озерам обычно не учитывается, но, на наш взгляд, он играет важную роль в формировании состава их вод наряду с испарением [Shvartsev et al., 2014; Borzenko and Shvartsev, 2019].

В настоящей работе впервые представлен наиболее полно материал по изотопному составу природных вод, углерода и кислорода растворенных и осажденных в донные осадки карбонатов, бактериальных обрастаний, а также кислорода водовмещающих пород и донных осадков озер Восточного Забайкалья. Все эти исследования проведены с целью 
выделения основных механизмов, контролирующих формирование разных типов и подтипов соленых озер.

\section{КРАТКОЕ ОПИСАНИЕ ИССЛЕДОВАННЫХ ОБЪЕКТОВ}

В Восточном Забайкалье распространены многочисленные озера. Все они приурочены к лесостепной и степной ландшафтно-климатическим зонам и расположены в бассейнах рр. Лены, Селенги, Онона, Аргуни, а также в пределах Улдза-Торейского бессточного бассейна (Рис. 1). С запада и востока территория ограничена координатами $112-$ $118^{\circ}$ в.д., с севера - широтой $52^{\circ}$, с юга $-49^{\circ}$ (государственной границей с Республикой Монголия и КНР). Климат рассматриваемой территории резко континентальный, семиаридный [Обязов, 1996]. Маломощный снежный покров образуется в начале ноября и сходит в конце апреля до таяния льда, поэтому питание водоемов талыми снеговыми водами отсутствует. Основная масса атмосферных осадков выпадает летом. Большинство водотоков, питающих озера, представлено ручьями, протяженность которых не превышает 25 кM.

Озерная система северо-западной территории региона относится к бассейнам стока pр. Селенга и Лена и находится в Беклемишевской впадине, в которой насчитывается около двух десятков преимущественно пресных озер. Впадина протяженностью более 100 км представляет собой слабо всхолмлённую равнину с абсолютными отметками 950-980 м, сложенную осадочными и базальтоидными формациями верхнеюрско-нижнемелового возраста. Эти формации прикрыты четвертичными континентальными отложениями небольшой мощности. Ее горное обрамление выполняют магматические и метаморфические породы протерозоя и палеозоя. Следующая группа изученных озер, отделенных от первых Яблоновым хребтом, относится к Амурскому водосборному бассейну и локализована в днище Читино-Ингодинской впадины с абсолютными отметками 740-900 м и протяженностью около 260 км. Окружающие хребты ее в основном сложены гранитами и гнейсами, сама впадина заполнена песчаниково-алевролитовыми породами мезозоя и рыхлыми четвертичными отложениями [Итигилова и др., 2002]. В этом районе также находятся преимущественно пресные озера, среди соленых насчитывается около 10 озер.

На юго-востоке территории значительную часть площади занимает ОнонскоАгинская и Улдза-Торейская равнины (последняя представляет собой северную часть более крупной морфоструктуры - Далайнорской равнины), изрезанные неглубокими падями, простирающимися на несколько километров каждая. В понижениях и котловинах 
сосредоточены многочисленные соленые озера. Большая часть их локализована в Цасучейской впадине. Впадина с поверхности сложена среднеплейстоценовыми песчаноглинистыми осадками мощностью до 100 м, перекрывающими эффузивно-осадочные меловые породы, выходящие на дневную поверхность в районе Торейских озер. Породы представлены преимущественно алевролитами, песчаниками, базальтами, трахиандезибазальтами, их кластолавами и туфами. За пределами впадины в выступах фундамента распространены гранитоиды мезозоя и метаморфические породы палеозоя, в составе которых значительную долю занимают сланцы, гнейсы, известняки, аргиллиты и алевролиты [Borzenko et al., 2020]. Рельеф района преимущественно низкогорный, пологохолмистый и равнинный с абсолютными высотами 596-800 м. Минимальная отметка находится в самой южной части в районе оз. Зун-Торей.

\section{МАТЕРИАЛЫ И МЕТОДЫ ИССЛЕДОВАНИЙ}

В данной статье представлены результаты гидрохимических исследований озер, выполненных в период 2013-2019 гг. Всего было изучено 107 соленых озер, 23 пресных озера, 129 подземных вод, 14 рек, 14 атмосферных осадков. Пробы воды отбирались на общий химический анализ, микрокомпонентный и изотопный состав, различные формы серы, минеральный состав донных отложений, также отбирались соли и минералы, собранные в седиментационные ловушки. Быстро изменяющиеся параметры pH, $\mathrm{O}_{2}$, Eh, температуру, электропроводность определяли с помощью прибора AMTASTAMT03 (США) непосредственно на месте отбора проб. Воду фильтровали в полевых условиях через стерильный ацетат-целлюлозный фильтр с размером пор 0.45 мкм на вакуумной фильтровальной установке ПВФ-47/ЗНБ.

Общий химический анализ проводили стандартными методами. Концентрации Са и $\mathrm{Mg}$ определяли методом атомного поглощения в азотно-ацетиленовом пламени с использованием спектрофотометра SOLAAR 6M. Определение Na и K основано на пламенно-эмиссионном методе. $\mathrm{F}$ и $\mathrm{Cl}$ определяли потенциометрически с использованием ионоселективных электродов. Титрование использовали для определения содержания ионов $\mathrm{CO}_{3}^{2-}$ и $\mathrm{HCO}_{3}^{-}$(TDIC). Сульфат-ионы $\mathrm{SO}_{4}{ }^{2-}$ анализировали турбидиметрическим методом в виде $\mathrm{BaSO}_{4}$ Микрокомпонентный состав определялся методом массспектрометрии с индуктивно-связанной плазмой на приборе ELEMENT-2 (Finnigan MAT, Германия) по методике НСАМ №480Х.

На изотопный состав воды было проанализировано 177 проб воды, из них 14 атмосферных осадков, 47 подземных вод, 7 речных, 22 пресных и 92 соленых озера. 
Анализ изотопного состава воды $\left(\mathrm{D},{ }^{18} \mathrm{O}\right)$ проводили с помощью изотопного массспектрометра с элементным анализатором TC/EA-IRMS (Finnigan MAT 253, Thermo Scientific, США). Изотопный состав рассчитывался в соответствии со стандартом океанской воды (VSMOW). Аналитическая погрешность составляет $1 \sigma$ для кислорода \pm 0.1 \%о и для водорода $\pm 1.0 \%$ \%.

Анализ изотопов кислорода и углерода растворенных карбонатов TDIC проведен в 139 образцах, из них 30 в подземных водах, 11 пресных озерах и 98 соленых. Образцы растворенных карбонатов для изотопного анализа получены осаждением $\mathrm{CaCl}_{2}$, реактив засыпали в пластиковые бутылки (1.5 л) непосредственно при отборе проб. Образование осадка происходило в течение непродолжительного времени, что исключает возможность изотопного обмена между ним и растворенным органическим углеродом. Образцы для определения изотопного соотношения $\delta^{13} \mathrm{C}$ растворенных карбонатов готовили к анализу по стандартной методике разложения карбонатов в 100\% - ной фосфорной кислоте в вакуумных условиях при температуре $95{ }^{\circ} \mathrm{C}$. Выделенный $\mathrm{CO}_{2}$ очищали криогенным методом разделения. Измерения произведены с использованием двойной системы напуска относительно лабораторного стандарта, калиброванного по международным стандартам NBS-18, NBS-19 и IAEA-CO-8. Воспроизводимость результатов (1б) составила 0.1 \%о для $\delta^{13} \mathrm{C}$. Изотопные соотношения приведены в соответствии со стандартом VSMOW и VPDB.

Донные осадки отбирались дночерпателем Петерсена из центральной части озер. Седиментационные ловушки, крепились на веревку с грузом через каждый метр (5 м) и опускались в прорубь меромиктического оз. Доронинское. Ловушки устанавливались в начале декабря и снимались в конце марта. Рентгенофазовый анализ (РФА) применялся для исследования пелитовой фракции донных отложений (60 проб) и материала из седиментационных ловушек (5 проб) на аппарате ДРОН-3 (Браун, 1965). Количественное соотношение компонентов рассчитано по корундовым числам методом RIR (Hubbard and Snyder, 1988). Микрозондовый анализ на микроскопе МБС-10 применялся для определения минерального состава горных пород прибрежной части озер (11 проб).

В 55 образцах карбонатов донных осадков TIC, 26 образцов бактериальных матов ВОС определен $\delta^{18} \mathrm{O}$ и $\delta^{13} \mathrm{C}$. В 29 пробах алюмосиликатной фракции донных отложениях озер и 20 пробах горных пород прибрежной части озер определен $\delta^{18} \mathrm{O}-\mathrm{SiO}_{2}$. Все пробы сушились и измельчались до «пылеватой» фракции. Определения изотопов кислорода и углерода карбонатов и бактериальных матов выполнены на том же приборе и теми же методами что и для TDIC. 
Подготовка образцов для определения величин $\delta^{18} \mathrm{O}-\mathrm{SiO}_{2}$ в алюмосиликатной фракции прибрежной горной породы и донных отложений проводилась с использованием метода лазерного фторирования (ЛФ) на опции “лазерная абляция с экстракцией кислорода из силикатов” в присутствии реагента $\mathrm{BrF}_{5}$ по методу (Sharp, 1990). В ее комплект входит установка MIR 10-30 системы лазерного нагрева с лазером $\mathrm{CO}_{2}$ мощностью 100 вт и длиной волны 10.6 мкм в инфракрасной области, позволяющий разогревать анализируемые минералы до $1000^{\circ} \mathrm{C}$, что дает возможность анализировать даже самые тугоплавкие минералы (оливин, циркон, гранат) и вакуумная магистраль для очистки выделенного газа с криогенными ловушками и специальным сорбентом, охлаждаемым жидким азотом, для окончательного концентрирования кислорода. Проведение реакции осуществляется в оперативном режиме с полным контролем по монитору, что позволяет визуально контролировать ход реакции и полноту разложения образца, менять режим (мощность и фокусировку лазерного луча) для достижения полного сгорания образца. При ЛФ не происходит фракционирования кислорода из-за малого времени проведения реакции и высокой температуры. На разложение одного образца требуется не более 15-20 минут, что сводит к минимуму возможность загрязнения полученного газа атмосферными примесями.

Для изотопного анализа кислорода использовались только чистые минералы (с предварительным удалением карбонатов). Расчеты $\delta^{18} \mathrm{O}_{-} \mathrm{SiO}_{2}$ были выполнены относительно международных стандартов NBS-28 (кварц) и NBS-30 (биотит). Правильность полученных значений контролировалась регулярными измерениями собственного внутреннего стандарта ГИ-1 (кварц) и лабораторного ИГЕМ РАН Polaris (кварц). Изотопные соотношения приведены в соответствии со стандартом SMOW. Погрешность полученных значений величин $\delta^{18} \mathrm{O}$ находилась на уровне (1s) $\pm 0.2 \%$.

Термодинамические расчеты равновесия воды с горной породой проведены с использованием программы «Geochemist's Workbench (GWB 14)» (Bethke and Yeakel, 2016). При пересыщении вод относительно какого либо соединения значение индекса Q/K $>0$, отрицательное значение свидетельствует о неравновесности системы, в случае $\mathrm{Q} / \mathrm{K}=0$ - равновесие воды с минералом. С помощью этой программы рассчитан химический тип природных вод. Дополнительно соленые озера были разделены на типы на основании значений $\mathrm{pH}$ и содержания ведущих анионов. К содовым озерам отнесены озера с $\mathrm{pH} \geq 9.0$. Ввиду того, что в химическом составе содовых озер зачастую количество $\mathrm{CO}_{3}{ }^{2-}+\mathrm{HCO}_{3}{ }^{-}$не является преобладающим в общем балансе анионов, они были разделены на подтипы, к I подтипу отнесены озера $\mathrm{Na}-\mathrm{CO}_{3}-\mathrm{HCO}_{3}$ состава, ко II подтипу - $\mathrm{Na}-\mathrm{SO}_{4}$ и к III подтипу - 
$\mathrm{Na}-\mathrm{Cl}$. K хлоридному типу отнесены озера с $\mathrm{pH}<9.0$ и $\mathrm{Na}-\mathrm{Cl}$ составом, а сульфатным, если $\mathrm{pH}<9.0$ с Na-SO${ }_{4}$ составом.

\section{РЕЗУЛЬТАТЫ ИССЛЕДОВАНИЯ}

\section{Изотопный состав природных вод.}

Анализ полученного материала показал, что наиболее тяжелая дождевая вода $\left(\delta^{18} \mathrm{O}\right.$ -10.5 и -72 \%о) приходится на самую юго-восточную точку района исследований, а легкая

Табл. 1

Рис. 2

Табл. 2 (-12.8 и -108 \%о) на северо-западную часть, по средним оценкам значение изотопных соотношений для дождевых вод составляет для $\delta^{18} \mathrm{O}--12.9$ и $\delta \mathrm{D}--94$ \%о в летние месяцы (табл. 1).

В целом отмечается прямая зависимость в распределении значений $\delta \mathrm{D}$ от координат местности и ее высотных отметок (рис. 2).

Соленость и рН атмосферных осадков варьирует в узком диапазоне от 0.02 до 0.04 мг/л и от 5.1 до 6.8 соответственно. По химическому составу они относятся к Ca-HCO типу.

Для построения локальной линии метеорных вод включены данные по изотопам зимних осадков (снег). Согласно полученным данным они имеют облегченный изотопный состав (среднее $\delta^{18} \mathrm{O}--17.4$ и $\delta \mathrm{D}--130$ \%). В целом, включая летние и зимние показатели, соотношение $\delta \mathrm{D}$ и $\delta^{18} \mathrm{O}$ атмосферных осадков региона подчинено линейной зависимости, которая описывается уравнением: $\delta \mathrm{D}=8.0 \delta^{18} \mathrm{O}+9.2$.

Изотопный состав подземных вод, локализованных на водосборных территориях озер, варьирует от -13.9 до -8.9 по кислороду и от -108 до -70 \%о по дейтерию (табл. 2).

Облегченный состав имели воды, отобранные из наиболее высокодебитного источника (> 1 л/с), а наиболее тяжелый - низкодебитного (<0.003 л/с) родника. Среднее значение изотопного состава вод составляет -12.1 для $\delta^{18} \mathrm{O}$ и -94 \%о для $\delta \mathrm{D}$. По генезису все они относятся к метеорным водам [Craig, 1961]. Химический состав изученных подземных вод представлен для маломинерализованных водопроявлений $\mathrm{Ca}-\mathrm{HCO}_{3}$ типом, который с ростом солености (среднее 0.68 г/л) и $\mathrm{pH}$ (среднее 7.8) меняется на $\mathrm{Mg}-\mathrm{HCO}_{3}{ }^{-}$, a при дальнейшем росте этих показателей (среднее 1.15 г/л, pH> 8.2) на Na-HCO 3 (Borzenko et al., 2020). Для большинства точек, относящихся к подземным водам, характерно смещение относительно линии метеорных вод LMWL (рис. За).

Левостороннее смещение принято объяснять обогащением воды ${ }^{16} \mathrm{O}$ за счет обмена ${ }^{18} \mathrm{O}-\mathrm{H}_{2} \mathrm{O}$ на ${ }^{16} \mathrm{O}-\mathrm{CO}_{2}$ [O’Neil et al., 1975], а правостороннее смещение за счет: 1) испарения 
воды, 2) смешения седиментационных морских и метеогенных вод [Clark, 1997 и др.]; 3) кислородного обмена легкого изотопа воды на тяжелый изотоп вмещающих пород [Ферронский, Поляков, 2009 и др.]. Для рассматриваемой района исключается присутствие морских седиментационных вод [Чабан и Беляков, 1977]. Также в большинстве случаев исключается влияние испарения, т.к. уровень воды в исследованных скважинах не превышал 15 м от поверхности земли, что ниже горизонта подверженного испарению [Минеральные воды..., 1969]. Очевидно, что основная причина правостороннего отклонения это результат взаимодействия воды с алюмосиликатными вмещающими породами.

По приведенному выше уравнению метеорных вод была рассчитана соответствующая величина для $\delta^{18} \mathrm{O}$ с учетом измеренного значения $\delta \mathrm{D}$, поскольку считается, что из-за несопоставимо малого содержания водорода в породах по сравнению с циркулирующей в них водой при относительно низких температурах обмен его изотопами между водой и породой незначим. Далее, по разности между измеренными и рассчитанными значениями получена величина кислородного сдвига $\Delta \delta^{18} \mathrm{O}$, которая чаще имеет положительное значение (-1.1 - 2.9, среднее 0.7 \%о). И только в случае, если воды

Puc. 4

Рис. 5
Табл. 3 обогащены растворенным углекислым газом $\mathrm{CO}_{2}, \Delta \delta^{18} \mathrm{O}$ приобретает отрицательное значение (рис. 4а). Как правило, это воды имеют относительно низкое значение рН, отсюда проявляется прямая зависимость $\Delta \delta^{18} \mathrm{O}$ от рН (рис. 4б).

Следующий прием, который был применен для выяснения генезиса вод, заключался в следующем. Подставив измеренное значение $\delta \mathrm{D}$ в уравнения « $\delta \mathrm{D}-$ координаты местности», описывающие зависимости для атмосферных осадков (уравнения на рис. 2), были вычислены гипотетические координаты точек области питания подземных вод. Расчеты показали, что расстояние от области питания до разгрузки подземных вод варьирует от 1 до 25 км. Можно предположить, что чем больше расстояние, тем больше времени вода циркулирует в породе, взаимодействует с ней, в результате чего должны меняться гидрогеохимические параметры. Вероятно, отсюда проявляется связь расстояния $\mathrm{S} \mathrm{c} \Delta \delta^{18} \mathrm{O}$ и $\mathrm{pH}$ воды (рис. 5).

Изотопный состав рек и ручьев, питающих озера, варьирует по $\delta^{18} \mathrm{O}$ от -13.3 до -7.1 и по $\delta \mathrm{D}$ от -102 до -69 \%о, со средними значениями соответственно -11.6 и -92 \%о (табл. 3). По средним оценкам соленость речных вод составляет 0.20 г/л, а рН 7.7. Реки с модулем стока более 0.1 л/с км² менее минерализованные (до 0.2 г/л) и относятся к Са-НСО $\mathrm{Ca}-\mathrm{SO}_{4}$ типам. Повышенная минерализация (до 5 г/л) и $\mathrm{pH}$ (7.9) отмечалась в ручье с 
модулем стока около 0.003 л/с км², по химическому составу он относится к $\mathrm{Na}-\mathrm{Cl}$ типу.

Диапазон варьирования гидроизотопных данных для изученных озер (табл. 4) укладывается в рамки существующего ряда, определенного для континентальных бассейнов [Craig, 1961]. Наиболее легкий изотопный состав воды $\left(\delta^{18} \mathrm{O}--13.1\right.$ и $\delta \mathrm{D}--108$ \%) установлен в солоноватом содовом озере с соленостью 3.3 г/л и рН 9.2. Максимальное значение $\delta \mathrm{D}$ (-23 \%) определено в рассоле самого соленого (185 г/л) хлоридного озера, при значении $\delta^{18} \mathrm{O}=2.0$ \%. Наиболее тяжелый кислород воды $\left(\delta^{18} \mathrm{O}=2.1\right.$ \%о) выявлен в содовом солоноватом озере (соленость 7.1 г/л), но с высоким значением рН (9.8).

В пресных озерах $(\mathrm{M} \leq 1$ г/л) при солености 0.3 г/л и рН 7.7 значение изотопных соотношений составляет в среднем $\delta^{18} \mathrm{O}--7.7$ и $\delta \mathrm{D}-72$. Эти озера относятся к Ca-HCO типу. С ростом солености и $\mathrm{pH}$ вод (среднее $\mathrm{M}=0.5$ г/л) и $\mathrm{pH}$ (среднее 8.1) формируются озера $\mathrm{Mg}-\mathrm{HCO}_{3}$ или $\mathrm{Na}-\mathrm{HCO}_{3}$ типов. Параллельно накапливаются и тяжелые изотопы воды (среднее $\delta^{18} \mathrm{O}--6.9 \%$ и $\delta \mathrm{D}-68 \%$ ).

Табл. 5

Среди соленых озер (M>1 г/л) наибольшее распространение имеют содовый тип (табл. 5). Количество хлоридных типов существенно меньше, а сульфатные установлены в единичных случаях. Соленость озерных вод за период исследований достигала 343 г/л (содовое оз. Борзинское), а величина рН воды изменялась от 7.5 до 10.7 (табл. 4). Повсеместно среди катионов резко доминирует натрий, концентрация которого по мере роста солености вод увеличивается. В среднем содержание кальция в содовых озерах ниже, чем хлоридных и сульфатных. Последние два типа отличаются относительно низким содержанием карбонатов, то время как в содовом типе их содержание остается высоким с максимальным количеством во II подтипе. В больших масштабах в последнем концентрируется и сульфат-ион. Более сложной оказалась зависимость солености от рН

Рис. 6 вод, т.е. в содовых озерах значение $\mathrm{pH}$ воды растет с ростом солености, а в хлоридных и сульфатных, наоборот уменьшается (рис. 6).

Широкое варьирование химического состава, значений $\mathrm{pH}$ и минерализации озерных вод предполагает существенные вариации их изотопного состава. По средним оценкам наиболее легкая вода принадлежит пресным озерам $\left(\delta^{18} \mathrm{O}--7.0\right.$ и $\left.\delta \mathrm{D}--70 \%\right)$, а наиболее тяжелая по $\delta \mathrm{D}$ (-43 \%о) - более соленым хлоридным, а по $\delta^{18} \mathrm{O}(-2.0 \%$ \%) - содовым озерам II подтипа.

$\mathrm{B}$ поверхностных водоемах в результате процессов испарения содержания $\mathrm{D}$ и ${ }^{18} \mathrm{O}$ всегда превышают их концентрации в атмосферных осадках, реках и подземных водах зоны активного водообмена. Считается, что угловой коэффициент зависимости $\delta \mathrm{D}$ и $\delta^{18} \mathrm{O}$ в 
водах, подвергшихся испарению, уменьшается до величины, меньшей по сравнению с угловым коэффициентом линии тренда изотопных соотношений атмосферных осадков. В сравнении с подземными водами и реками точки, относящиеся к озерам, расположены существенно правее линии тренда метеорных вод (рис. 3б). Более того, между типами озер также имеются отличия, выраженные через разные значения коэффициентов уравнения регрессии, указывающие на разную степень влияния процесса испарения на изотопный состав их вод. Поэтому в первую очередь, необходимо выяснить степень влияния процесса испарения на каждый тип озер.

С помощью программного обеспечения «Гидрокалькулятор» [Skrzypek et al., 2015] можно оценить потери на испарение из отдельных бассейнов аридных и семиаридных регионов, зная изотопный состав вод, участвующих в формировании водного баланса озер. В рассматриваемом регионе период открытой ото льда воды длиться с мая-по сентябрь, среднесуточная температура в эти месяцы составляет $14{ }^{\circ} \mathrm{C}$, а относительная влажность 65 \% [Обязов, 1996]. Для расчета степени испарения $f$ была выбрана модель - «бассейны с нестационарными условиями», потеря воды в которой происходит исключительно за счет испарения. Для пресных озер выбрана модель «бассейны со стационарными условиями». За начальное значение изотопов воды принята средняя величина $\delta \mathrm{D}$ и $\delta^{18} \mathrm{O}$ для подземных вод, а за конечное - измеренное в конкретном озере. За величину изотопного состава атмосферных осадков принято среднее значение $\delta^{18} \mathrm{O}$ и $\delta \mathrm{D}$ атмосферных осадков. Линия LEL построена по данным $\delta^{18} \mathrm{O}$ и $\delta \mathrm{D}$ (рис. За, уравнение (1)) хлоридных озер, т.к. значения гидроизотопных соотношений увеличиваются прямо пропорционально росту солености их вод [Борзенко, 2018]. За конечный результат выбраны значения, рассчитанные по $\delta \mathrm{D}$. Условно принимая, что вариации значений $\delta \mathrm{D}$ определяются исключительно процессом испарения. Результаты расчетов представлены в табл. 4.

Согласно расчетам получается, что в хлоридных озерах в среднем испаряется больший объем воды $(f=0.55)$, чем сульфатных $(f=0.41)$ и тем более содовых $(f=0.38)$. Внутри содового типа отмечается постепенное увеличение величины степени испарения от I к III подтипу. Такие высокие в целом значения степени испарения и их существенные различия для разных типов соленых озер и внутри каждого типа вполне возможны, поскольку степень реального испарения воды зависит от многих факторов: площади озера, его глубины, объема воды, высоты местности, где расположено озеро, соотношения площади озера с водосборной площадью и т.д.

Справедливость полученных цифр в целом подтверждается и проведенными нами расчетами водного баланса для некоторых озер [Borzenko, Shvartsev, 2019]. В содовых 
озерах отношение приходной части водного баланса к расходной колеблется в пределах 0.60-0.99, а в хлоридных оно значительно ниже и составляет только 0.46-0.52. В первых в приходной части их водного баланса наряду с подземными водами и атмосферными осадками зачастую принимают участие реки и ручьи. Как правило, они имеют больший объем воды (табл. 4). Хлоридные озера питаются исключительно грунтовыми водами и атмосферными осадками. Все соленые озера бессточные, а испарение с водной поверхности является основной расходной частью их водного баланса [Иванов, 1978].

B пресных озерах среднее значение соотношения $\mathrm{E} / \mathrm{I}=0.30$ (испарение/приток воды), т.е. 28 \% объема притока испаряется. И это понятно, т.к. пресные озера проточные, с большим объемом воды (табл. 4).

Анализ полученных данных показал, что связь солености со степенью испарения воды $f$ прослеживается исключительно для хлоридных и сульфатных озер и отсутствует для содовых (рис. 7а). Такое положение в очередной раз подтверждает, что в формировании состава последних процесс испарения не является основным. В тоже время, для всех типов соленых озер прослеживается обратная зависимость $f$ от $\mathrm{pH}$ (рис. 7б), значение которого определяется преимущественно содержанием TDIC, отсюда согласованность в распределения значений рН и TDIC (рис. 7в).

\section{$\delta^{18} \mathrm{O}$-TDIC, $\delta^{18} \mathrm{O}-\mathrm{SiO}_{2}$ пород прибрежья, $\delta^{18} \mathrm{O}$-TIC и $\delta^{18} \mathrm{O}-\mathrm{SiO}_{2}$ донных осадков, $\delta^{18} \mathrm{O}-$ ВОС бактериальных матов}

Анализ $\delta^{18} \mathrm{O}$-TDIC показал, что его значение изменяется от 30.9 (содовый II подтипа) до 16.4 \%о (подземные воды) (табл. 4 и 2). Установлена связь между $\delta^{18} \mathrm{O}-\mathrm{H}_{2} \mathrm{O}$ и $\delta^{18} \mathrm{O}$-TDIC (рис. 8). Эта зависимость указывает на то, что TDIC по кислороду в значительной степени наследует изотопный состав воды. Но кислород TDIC существенно тяжелее кислорода воды, т.к. при взаимодействии ее с $\mathrm{CO}_{2}$ происходит фракционирование кислорода с переходом тяжелого изотопа в углекислотные ионы. Следовательно, сама вода

Pис. 8 при этом по кислороду становится более легкой, что наглядно представлено обратной зависимостью между $\delta^{18} \mathrm{O}-\mathrm{TDIC}$ и $\delta^{18} \mathrm{O}-\mathrm{H}_{2} \mathrm{O}$ по оз. Доронинское, опробование которого проводилось многократно [Borzenko et al., 2018]. Коэффициент фракционирования для кислорода в системе $\mathrm{H}_{2} \mathrm{O} \rightarrow$ TDIC варьирует в диапазоне $1.023 \leq \mathrm{K} \leq 1.043$ со средним значением 1.029.

Помимо воды изучался изотопный состав кислорода и углерода прибрежных пород и донных отложений. В статье приводятся отдельные данные, характеризующие изотопный состав кислорода горных пород (табл. 6). 
В горных породах прибрежной зоны озер наиболее легкий кислород определен в оливиновом метадолерите $\left(\delta^{18} \mathrm{O}_{-} \mathrm{SiO}_{2} \quad 6.7-6.9\right.$ \%о), наиболее распространенном на водосборах содовых озер Байн-Булак, Малая и Большая Якши и др. Метагиалобазальты, развитые на водосборах содовых озер Хадатуй, Ганга-Нур, Борзинское и др., имеют близкие соотношения $\delta^{18} \mathrm{O}-\mathrm{SiO}_{2}$ с метабазальтами на водосборе содовых Малая и Большая Булугунда и хлоридного Дабаса-Нор, значения которых варьируют в диапазоне от 8.0 до 8.6 \%. Изотопно-тяжелее кислород горных пород в районе содового оз. Худуктуй, состоящих преимущественно из мрамора и кварца (12.5 \%о). Относительно высокое значение $\delta^{18} \mathrm{O}_{-} \mathrm{SiO}_{2}(14.2-15.2$ \%) приходится на сланцевидный кварцит, распространенный в прибрежье содового оз. Хоточей, и полимиктовый песчаник в прибрежье содовых озер Куджертай и Доронинское и др. и метаморфизованный пепловый туф с включениями кварца в прибрежье содового оз. Байн-Цаган.

Минеральный состав донных отложений озер представлен преимущественно разными соотношениями полевых шпатов (плагиоклазы (чаще альбит) и КПШ) и кварца с примесью минералов смектит-каолинит-гидрослюдного состава, карбонатов (чаще кальцит и доломит). При этом доля глинистого и карбонатного материала более весомая в содовых озерах (табл. 7). В пресных озерах зачастую карбонатный материал присутствует в следовых количествах или отсутствует вовсе.

Считается, что полевые шпаты привносятся в озера с территории водосбора. С целью выявления их генезиса в период ледостава (во избежание эолового переноса минеральных частиц) в центральной части, на разных глубинах меромиктического содового соленого (> 30 г/л) оз. Доронинское были установлены седиментационные ловушки, в которых спустя 3 месяца повсеместно был обнаружен альбит $\mathrm{NaAlSi}_{3} \mathrm{O}_{8}$. Это доказывает, что среди кислых полевых шпатов возможно образование аутигенного альбита. Понятно, что в донных осадках доля его несравнимо мала по сравнению с терригенным. Помимо альбита в массе минералов определен кальцит $\mathrm{CaCO}_{3}$, на долю которого приходилось до 80 \%. В меньших количествах выявлены оксиды и оксигидроксиды железа: маггемит $\mathrm{Fe}_{2} \mathrm{O}_{3}$, лепидокрокит $\mathrm{FeO}(\mathrm{OH})$, гётит $\mathrm{FeO}(\mathrm{OH})$, которые установлены на границе смены сероводородной на глеевую обстановку $(0<\mathrm{Eh}<100$ мВ). В следовых количествах были определены доломит $\mathrm{CaMg}\left(\mathrm{CO}_{3}\right)_{2}$, моногидрокальцит $\mathrm{CaCO}_{3} \cdot \mathrm{H}_{2} \mathrm{O}$ и несквегонит $\mathrm{MgCO}_{3} \cdot\left(\mathrm{H}_{2} \mathrm{O}\right)_{3}$.

В большинстве случаев значение $\delta^{18} \mathrm{O}-\mathrm{SiO}_{2}$ алюмосиликатной фракции донных осадков существенно отличается от такового пород прибрежной части. В алюмосиликатной фракции донных осадков наиболее изотопно-легкий кислород (4.9 \%о) 
определен в пресном оз. Иван, а наиболее тяжелый (15.9 \%о) - в содовом оз. Хужарное с относительно высоким значением рН (9.7).

В карбонатной фракции ТIC донных осадков, в состав которых входят чаще кальцит и доломит, в единичных случаях гейлюссит $\mathrm{Na}_{2} \mathrm{Ca}\left(\mathrm{CO}_{3}\right)_{2} \bullet 5 \mathrm{H}_{2} \mathrm{O}$, трона $\mathrm{NaHCO}_{3} \bullet \mathrm{Na}_{2} \mathrm{CO}_{3}$ и сода $\mathrm{Na}_{2} \mathrm{CO}_{3} \bullet 10 \mathrm{H}_{2} \mathrm{O}$, значение $\delta^{18} \mathrm{O}$ меняется от 21.0 в кальците до 40 \%о в смеси соды и троны, при среднем значении 27.0 \%о по всей выборке. В обнаруженном в донных осадках оз. Доронинское гейлюссите значение $\delta^{18} \mathrm{O}$ равно 34.3 \%. Для доломита значение $\delta^{18} \mathrm{O}$ варьирует от 27.0 до 29.0 \%. Очевидно, что разница в изотопных соотношениях кислорода карбонатов определяется преимущественно долей присутствующих в донных отложениях кальцита, доломита, реже гейлюсита и соды.

В тоже время, в целом значение $\delta^{18} \mathrm{O}$ зависит от доли присутствующих здесь первичных и вторичных минералов, получается, чем больше доля аутигенной глинистой и карбонатной составляющей и меньше доля обломочного кварца и полевого шпата, тем изотопно-тяжелее по кислороду донные осадки. По средним оценкам по кислороду алюмосиликатная фракция изотопно-тяжелее воды в среднем на 19 \%о (1.010 $\mathrm{K} \leq 1.029)$, а карбонаты донных осадков - на 32 \% (1.023 $\leq \mathrm{K} \leq 1.045)$.

Для оценки влияния на изотопный состав озерной воды всех компонентов среды определялось также значение $\delta^{18} \mathrm{O}$ бактериальных обрастаний (маты), основных продуцентов органического вещества в рассматриваемых соленых озерах [Солоноватые..., 2009]. В период опробования озер маты представляли собой многослойный «пирог», состоящий из разноцветных слоев. По данным [Абидуева и др., 2006] верхний слой зеленого цвета состоял из эукаритических водорослей (Chorella minitisima), цианобактерий (видов Microcoleus chthonoplastes, Aphanothece salina, Promidium и др.), осуществляющих оксигенный фотосинтез. Средний слой рыжего или пурпурного цвета это зона аноксигенного фотосинтеза, который осуществляет группа пурпурных бактерий (окисляющих сероводород) преимущественно родов Chromatium Ectothiorodospera, и нижний слой черного цвета - зона сульфатредукции, представленная преимущественно сульфат- и сероредуцирующими бактериями, участвующими в разложении полимеров и продуктов брожения. По нашим наблюдениям площадь обрастания матов может покрывать до 80 \% акватории озера, а толщина таких обрастаний достигает нескольких сантиметров.

В общей массе бактериальных матов изотопные соотношения $\delta^{18} \mathrm{O}-\mathrm{BOC}$ варьируют от 16.6 до 29.8 при среднем значении 25.4 \%о. Среднее значение коэффициента фракционирования в системе $\mathrm{H}_{2} \mathrm{O}$ - ВОС равно 1.031, с накоплением ${ }^{18} \mathrm{O}$ в матах. В 
сопоставимых количествах ${ }^{18} \mathrm{O}$ присутствует в TDIC и TIC донных осадков, в тоже время в области повышенных значений $\delta^{18} \mathrm{O}$ маты накапливают тяжелый изотоп в больших количествах. Вероятно, тяжелый изотоп кислорода в ВОС наследуется не только из $\mathrm{HCO}_{3}{ }^{-}$ и $\mathrm{CO}_{3}{ }^{2-}$, но также из $\mathrm{SO}_{4}{ }^{2-}$ при наличии в озере сульфатредукции, т.к. в данном случае органическое вещество окисляется кислородом $\mathrm{SO}_{4}{ }^{2-}$ [Леин, 2004]. Бактериальное восстановление сульфатов активно протекает и в бактериальных матах, и в донных отложениях, и в водной толще 84 \% исследованных озер [Borzenko, 2018]. Скорость сульфатредукции в ВОС, населенных преимущественного аноксигенными бактериями серного цикла, в менее соленых озерах изменяется от 1.34 до 12 мг S/л в день ${ }^{-1}$. В илах интенсивность сульфатредукции в среднем составляет 69.0 мг S/кг•сут. [Солоноватые..., 2009.].

\section{$\delta^{13} C$-TDIC, $\delta^{13} C$-TIC донных осадков и $\delta^{13} C$-ВОС бактериальных матов}

Помимо кислорода нами изучался $\delta^{13} \mathrm{C}$-TDIC, а также осажденных в донные осадки $\delta^{13} \mathrm{C}$-TIC и $\delta^{13} \mathrm{C}-$ ВOC. Оказалось, что TDIC озерной воды заметно обеднены ${ }^{13} \mathrm{C}$ по отношению к значениям $\delta^{13} \mathrm{C}$-TDIC, соответствующим изотопному равновесию с атмосферным $\mathrm{CO}_{2}$. При величине $\delta^{13} \mathrm{C}$ в атмосферном $\mathrm{CO}_{2}$ от -5 до -8 \% (среднее -7 \% [Галимов, 1968] и коэффициентах фракционирования в системах $\mathrm{CO}_{2} \rightarrow \mathrm{HCO}_{3}^{-}$и $\mathrm{CO}_{2} \rightarrow$ $\mathrm{CO}_{3}{ }^{2-} 1.014$ и 1.012, соответственно, по [Юдович и Кетрис, 1978] равновесные отношения $\delta^{13} \mathrm{C}$ растворенных карбонатов должны находиться в интервале 4.0-9.0 \%. По нашей выборке они не превышали 6.5 \% и в большинстве случаев имели отрицательные значения. Наиболее тяжелый углерод относится к содовому оз. Доронинское. Диапазон изотопного состава неорганического углерода исследованных озерных вод перекрывает интервал $\mathrm{HCO}_{3}^{-}$морской воды и осаждающихся из нее хемогенных карбонатов, соответственно от -3 до +1 \%о и $0 \pm 2$ \%, и по минимальной величине соответствует морским карбонатам, равновесным с биогенным $\mathrm{CO}_{2}$, имеющим $\delta^{13} \mathrm{C}-12$ \%о по [Zhu et al., 2013; Zamana and Borzenko, 2014].

Рис. 9

Несмотря на высокую дисперсию, прослеживается связь значения $\delta^{13} \mathrm{C}$ с содержанием в водах TDIC, между ними существует линейная зависимость (рис. 9а). При суммарном содержании $\mathrm{HCO}_{3}{ }^{-}+\mathrm{CO}_{3}{ }^{2-}$ в воде свыше 1 г/л по изотопному составу углерода озерные TDIC становятся аналогичными морским. При этом, наиболее легкий углерод относиться к хлоридным озерам, а наиболее тяжелый концентрируется в содовых озерах.

Измеренное значение $\delta^{13} \mathrm{C}$-TIC донных осадков рассматриваемых озер варьирует от -8.8 до 2.8 при среднем -3.1 \%о. Изотопно-легче углерод бактериальных матов, значение 
$\delta^{13} \mathrm{C}$-ВОС которых изменяется от -14.7 до 0.2 при среднем -5.3 \%. Широкий диапазон варьирования значений $\delta^{13} \mathrm{C}-\mathrm{BOC}$ отражает изотопный состав как первичных продуцентов, так и его потребителей. По всей выборке проявляется согласованность в распределении $\delta^{13} \mathrm{C}$-TDIC с $\delta^{13} \mathrm{C}$-TIC и $\delta^{13} \mathrm{C}$-BOC (рис. 9б). Такое положение объясняется генетической связью $\mathrm{CO}_{2}$ с метаном $\mathrm{CH}_{4}$ [Галимов, 1968], основным газом донных отложений озер. Интенсивность метаногенеза в донных отложениях исследуемых озер изменяется от 0.2 до 140 мклСН ${ }_{4} /$ кг [Солоноватые..., 2009]. Широкое варьирование значений $\delta^{13} \mathrm{C}$ матов объясняется следующим образом: поднимаясь из донного ила $\mathrm{CH}_{4}$ и $\mathrm{CO}_{2}$ в более богатые кислородом воды взаимодействуют с ней с образованием $\mathrm{HCO}_{3}{ }^{-}$и $\mathrm{CO}_{3}{ }^{2-}$ и в дальнейшем выпадают в осадок в виде карбонатов, поэтому несмотря на разделение изотопов в системе $\mathrm{CH}_{4}-\mathrm{CO}_{2}$ средний изотопный состав углерода органического вещества близок с изотопным составом углерода карбонатов.

Соотношения значений обоих изотопов $\delta^{13} \mathrm{C}-$ и $\delta^{18} \mathrm{O}-\mathrm{TIC}$ по озерам сильно варьируют, хотя отбор проб производился в одно время (лето), за исключением оз. Доронинское. Более того, исключительно в содовых озерах между ними существует линейная зависимость (рис. 9в). Очевидно, что ковариационные композиции, установленные между $\delta^{13} \mathrm{C}$ и $\delta^{18} \mathrm{O}$, свидетельствуют о том, что карбонаты имеют относительно длительное время пребывания в озере и демонстрируют, несмотря на изменения окружающей среды, относительную стабильность гидрологии бассейна содовых озер (Talbot, 1990).

\section{Термодинамические равновесия вод}

Для выяснения участия горной породы в формировании состава природных вод был рассчитан индекс равновесия $\mathrm{Q} / \mathrm{K}$ воды с наиболее распространенными минералами вмещающих пород и донных осадков озер. Анализ полученного материала позволил выявить следующие закономерности (табл. 8).

Для формирования кальцита необходимо, чтобы минерализация была более 0.6 г/л, a $\mathrm{pH}>7.3$. Незначительный рост $\mathrm{pH}$ и количества $\mathrm{Ca}^{2+}+\mathrm{Mg}^{2+}(>0.01$ г/л) приводит к насыщению вод по доломиту. Гейлюссит формируется исключительно в содовых озерах. В данном случае обязательными условиями являются: более высокое значение минерализации воды (> 10.0 г/л), $\mathrm{pH}$ (> 9.2), $\mathrm{HCO}_{3}{ }^{-}+\mathrm{CO}_{3}{ }^{2-}(>1.4)$ и $\mathrm{Na}^{+}$(> 2.4 г/л) (рис. 5в). Для насыщения вод по соде надо, чтобы соленость была более 130 г/л, $\mathrm{pH}>9.4, \mathrm{a} \mathrm{HCO}_{3}^{-}$ $+\mathrm{CO}_{3}{ }^{2-}>19.0$ и $\mathrm{Na}^{+}>44.0$ г/л. Гипс и мирабилит формируются в единичных случаях, но в разных озерах. Насыщение вод по гипсу отмечается в единственном хлоридном оз. 
Бильчир-Нуур, с соленостью 55 г/л, $\mathrm{pH}=8.47$, содержанием $\mathrm{Ca}^{2+}$ и $\mathrm{SO}_{4}^{2-} 0.6$ и 8.75 г/л соответственно. Мирабилит образуется в содовом оз. Борзинское с соленостью 343 г/л, $\mathrm{pH}=9.34$, концентрацией $\mathrm{Na}^{+} 125.0$ и $\mathrm{SO}_{4}{ }^{2-} 62.3$ г/л. В тоже время все природные воды остаются не равновесны с такими сульфатными минералами, как бледит, глауберит и эпсомит [Борзенко, 2020].

Возможность формирования аутигенных алюмосиликатных минералов, в частности глин и гидрослюд, продиктовано следующими условиями. Насыщение воды по каолиниту возможно уже при минерализации равной 0.1 г/л, $\mathrm{pH}=6.9$, содержании $\mathrm{Si}-0.37$ мг/л и $\mathrm{Al}$ 0.18 мкг/л. Для формирования монтмориллонитов и иллитов необходимо, чтобы солёность вод была более 0.2 г/л, $\mathrm{pH}>7.1-7.5$, а содержание $\mathrm{Si}>4.5$ мг/л. Мусковит образуются при относительно небольшой минерализации, но в более щелочной среде ( $\mathrm{pH}>7.7)$. Сепиолит образуются при солености свыше 1.0 г/л и рH> 8.5, с содержанием $\mathrm{Si}>5.0$ мг/л, такие условия чаще соблюдаются для содовых озер и реже для сульфатных и не характерны для хлоридных озер. Рост солености (> 8.0), $\mathrm{pH}$ (> 9.4), содержания Na (> 1.5 г/л) и ( $\mathrm{Si}>6.5$ мг/л) вод приводит к насыщению вод по альбиту. Такие условия складываются исключительно для более минерализованных и щелочных вод содовых озер.

В соответствии с полученными данными выходит, что состав того или иного вторичного минерала контролируется определенным химическим составом, $\mathrm{pH}$ и соленостью вод. При этом, чем выше значение $\mathrm{pH}$, тем к большему количеству минеральных новообразований вода приходит в равновесие. Заметим, что в наиболее щелочных и минерализованных содовых озерах достигается равновесие с гидрослюдой, некоторыми цеолитами и низкотемпературным альбитом. В то время как, в наиболее минерализованные хлоридные и сульфатные озера находятся на стадии формирования глинистых минералов, кальцита и доломита.

\section{ОБСУЖДЕНИЕ РЕЗУЛЬТАТОВ}

Проведенное исследование показывает, что природа формирования изотопного состава подземных вод определяется преимущественно степенью их взаимодействия с водовмещающими алюмосиликатными породами, растворение которых протекает по механизму гидролиза, предложенному У.Д. Келлером [Келлер, 1963]:

$$
\left.\mathrm{MeAlSiO}_{n}+\mathrm{H}_{2} \mathrm{O}=\mathrm{Me}^{n+}+\mathrm{OH}^{-}+\left[\mathrm{Si}(\mathrm{OH})_{0-4}\right]+\left[\mathrm{Al}^{\circ}(\mathrm{OH})_{6}\right]\right]_{n}^{3-},(1)
$$

где $n$ относится к неопределенным атомным соотношениям, $o$-к октаэдрическим координатам; Ме - катионы металлов. 
Свидетельством тому является существенно возросшая величина $\mathrm{pH}$, солености, содержания $\mathrm{Na}$, а также синхронное обогащение воды ${ }^{18} \mathrm{O}$, по мере уменьшения дебита родников и увеличения расстояния от области питания до области разгрузки подземных вод (табл. 2). По сути это значит, что чем дольше вода взаимодействует с породой, тем выше значения перечисленных показателей. В рассматриваемом случае, с самого начала отношение ${ }^{18} \mathrm{O} /{ }^{16} \mathrm{O}$ в растворяемой алюмосиликатной породе было выше, чем в атмосферных осадках, которые, попадая в породу, циркулируют в ней и растворяют ее, в результате вода обогащается тяжелым изотопом.

Из приведенной выше реакции следует, что чем интенсивнее идет растворение, тем выше концентрации $\mathrm{OH}^{-}$, при наличии биогенной $\mathrm{CO}_{2}$ образуется $\mathrm{HCO}_{3}^{-}$, а в дальнейшем и $\mathrm{CO}_{3}{ }^{2-}$ по реакции:

$$
2^{18} \mathrm{OH}^{-}+{ }^{12} \mathrm{C}^{16} \mathrm{O}_{2}=\mathrm{H}^{13} \mathrm{C}^{18} \mathrm{O}_{3}{ }^{-}+{ }^{16} \mathrm{OH}^{-}={ }^{13} \mathrm{C}^{18} \mathrm{O}_{3}{ }^{2-}+\mathrm{H}_{2}{ }^{16} \mathrm{O} \text {, (2) }
$$

с фракционированием изотопов кислорода, которое приведет $\mathrm{K}$ обогащению ${ }^{18} \mathrm{O}$ карбонатных ионов и обеднению воды.

При достижении равновесия подземной воды с кальцитом последний будет наследовать изотопный состав карбонатных ионов. В тоже время образование кальцита приведет к смене $\mathrm{Ca}-\mathrm{HCO}_{3}$ состава на $\mathrm{Mg}-\mathrm{HCO}_{3}$, а при достижении равновесия с доломитом далее на $\mathrm{Na}-\mathrm{HCO}_{3}$, который отличается уже большей величиной солености, $\mathrm{pH}$ вод, содержанием $\mathrm{Na}^{+}$и $\mathrm{HCO}_{3}^{-}$и более тяжелым изотопным составом воды и, соответственно, кислорода карбонатов. Для этих типов вод характерно насыщение не только по каолиниту и иллиту, но к ним добавляются монтмориллониты различного состава (Mt-Ca, Mt-Na, Mt-K). В тоже время равновесие воды с исходными первичными минералами преимущественно основного состава (анортит, форстерит, фаялит и др.), распространенных на водосборах озер (Борзенко, 2018), так и не достигается, поэтому они будут растворяться и являться источником химических элементов и тяжелых изотопов воды.

Очевидно, что среднегорный рельеф внешней области питания, небольшая мощность рыхлых отложений на водораздельных пространствах и склонах создают благоприятные условия для свободной инфильтрации атмосферных вод в зону трещиноватых пород и предопределяют направление движения трещинных вод к области разгрузки. У подножия склонов образуются многочисленные родники. Далее во впадинах дебиты снижаются до сотых и даже тысячных литров в секунду. Наблюдаемая картина 
объясняется разным водообменом или, что то же самое, разным временем взаимодействия [Shvartsev, 2000].

Попадая в озера, атмосферные, подземные и речные воды оказываются в условиях, где степень испарения их возрастает, что сопровождается концентрированием в них тяжелых изотопов воды. Однако в озерах вода продолжает взаимодействовать с породой, поэтому накапливаются $\mathrm{HCO}_{3}{ }^{-}$, а в дальнейшем $\mathrm{CO}_{3}{ }^{2-}$ и многие химические элементы REE, $\mathrm{F}^{-}, \mathrm{Si}, \mathrm{Al} . \mathrm{Zr}, \mathrm{Mo} \mathrm{и} \mathrm{др.} \mathrm{(табл.} \mathrm{5),} \mathrm{источником} \mathrm{которых} \mathrm{являются} \mathrm{водовмещающие} \mathrm{породы.}$ Взаимодействие воды с горной породой приводит к ее растворению и последовательному образованию вторичных минералов (гидроксидов, глинистых минералов, карбонатов, сульфатов, гидрослюд и др.) согласно законам термодинамики.

По данным [Savin and Epstein, 1970; Sheppard et al., 1971; и др.] в процессе гидролиза горных пород с участием метеорных вод происходит образование глинистых минералов в нормальных условиях, близких к равновесным, например, каолинита и смектита, последние обогащаются ${ }^{18} \mathrm{O}$ на 27 \%о и обедняются D на 30 \%о по сравнению с водой. Аутигенный альбит и кварц имеют значение $\delta^{18} \mathrm{O} 18.8$ и 10-12.5 \%о соответственно, при этом $\delta^{18} \mathrm{O}$ воды, находящейся с ними в равновесии, составляет 3 \%о (Savin and Epstein, 1970b). Карбонаты обогащены ${ }^{18} \mathrm{O}$ на 20-30 \%о по сравнению с водой.

На возможность разделения изотопов в результате взаимодействия воды с горной породой указывает утяжеление вод и по водороду за счет перехода $\mathrm{H}^{+}$во вторичные минералы как более легкого изотопа за счет изотопного кинетического эффекта. Существенное влияние на фракционирование водорода могут оказывать и бактериальные процессы путем избирательного поглощения микроорганизмами протия [Ферронский, Поляков, 2009]. Отсюда при относительно невысокой степени испарения озерных вод пресных и содовых озерах отмечается обогащение их и D. По данным [Matsuo et al., 1978] выпадение гейлюссита приводит к обогащению жидкой фазы дейтерием на 15 \%. Этими авторами доказано также, что обогащается вода дейтерием в случае кристаллизации соды и гидрогалита. Кристаллизация гипса ведет к его утяжелению ${ }^{18} \mathrm{O}$ на 4 \%о и обеднению D на $15 \%$ [Fontes, Gonfiantini, 1967].

Получается, если растворяемые водой первичные породы в среднем имеют $\delta^{18} \mathrm{O}$ 10.0 \%о, то образуемые ими аутигенные алюмосиликаты и карбонаты имеют уже более высокие значения (среднее 12.1 и 27 \%о соответственно), одновременно изотопно-тяжелее становится и вода. При этом, содержание ${ }^{18} \mathrm{O}$ в воде увеличивается тем больше, чем больше отношение между значением $\delta^{18} \mathrm{O}-\mathrm{H}_{2} \mathrm{O}$ и $\delta^{18} \mathrm{O}-\mathrm{MeAlSiOn}$ (1). Согласно данным таблицы 7 суммарная доля глины с карбонатами изменяется от 33 до $<1$ \% с максимумом 
для содовых озер II подтипа. В целом по всей выборке доля аутигенных минералов в осадках содовых озерах выше, чем в других типах водоемов. Понятно, что для образования такого количества вторичных минералов воде потребуется растворить больший объем горной породы.

Возможность трансформации изотопного состава вод в результате взаимодействия воды с горной породой подтверждается наличием «кислородного сдвига» $\Delta \delta^{18} \mathrm{O}-\mathrm{H}_{2} \mathrm{O}$, величина которого вычислена по разности между $\delta^{18} \mathrm{O}-\mathrm{H}_{2} \mathrm{O}$ измеренными и рассчитанными значениями, последние получены из уравнения для LEL. За $\delta \mathrm{D}$ взято измеренное значение $\delta \mathrm{D}-\mathrm{H}_{2} \mathrm{O}$ для каждой пробы. Полученные положительные числа указывают на обогащение воды тяжелым изотопом, а отрицательные - на ее обеднение. Несмотря на разброс точек, в целом имеет место согласованность в распределении значений $\Delta \delta^{18} \mathrm{O}$ и $\mathrm{pH}$ с величиной аппроксимации по всей выборке $\mathrm{R}^{2}=0.3$, усиливающийся с ростом $\mathrm{pH}$ вод в содовых озерах до 0.6 (рис. 10).

Очевидно, что взаимодействие воды с вмещающими породами сопровождается направленной трансформацией ее изотопного состава. По средним оценкам в содовых озерах значение $\Delta \delta^{18} \mathrm{O}$ равно $0.8 \%$ о, в сульфатных и хлоридных - -0.2 и -0.3 \%о, в пресных озерах и реках -0.3 и -0.4 соответственно. Внутри содового типа с переходом от I ко II и далее к III подтипу изменяется следующей последовательности: $0.8 \rightarrow 1.5 \rightarrow 0.5 \%$ соответственно. Относительно высокое значение $\Delta \delta^{18} \mathrm{O}$ во II подтипе можно объяснить следующим образом. Для формирования содовых озер II подтипа (как и сульфатных) необходимым условием является наличие дополнительного источника серы, в качестве которого на рассматриваемой территории выступают интрузивные породы, несущие сульфидную минерализацию [Борзенко, 2018]. Отсюда растворение водовмещающих пород можно представить в виде нескольких реакций:

$$
\begin{gathered}
\mathrm{FeS}_{2}+3.5 \mathrm{O}_{2}+\mathrm{H}_{2} \mathrm{O}=\mathrm{Fe}^{2+}+\mathrm{H}_{2} \mathrm{SO}_{4} \text {, далее } \\
0.5 \mathrm{CaAi}_{2} \mathrm{Si}_{2} \mathrm{O}_{8}+\mathrm{H}_{2} \mathrm{SO}_{4}+2 \mathrm{H}_{2} \mathrm{O}+\mathrm{CO}_{2}=\mathrm{Al}^{3+}+\mathrm{H}_{4} \mathrm{SiO}_{4}+0.5 \mathrm{Ca}^{2+}+\mathrm{SO}_{4}{ }^{2-}+\mathrm{HCO}_{3}{ }^{-}+\mathrm{OH}^{-} \\
\text {или } \\
\mathrm{NaAlSi}_{3} \mathrm{O}_{8}+\mathrm{H}_{2} \mathrm{SO}_{4}+6 \mathrm{H}_{2} \mathrm{O}+\mathrm{CO}_{2}=\mathrm{Al}^{3+}+3 \mathrm{H}_{4} \mathrm{SiO}_{4}+\mathrm{Na}^{+}+\mathrm{SO}_{4}{ }^{2-}+\mathrm{HCO}_{3}{ }^{-}+\mathrm{OH}^{-} \text {и т.д., }
\end{gathered}
$$
полнота которых определяется соотношением поступающих в раствор кислот и щелочей. В случае преобладания кислот формируются сульфатные озера, поэтому они менее щелочные $(\mathrm{pH}<9)$. Если преобладают щелочи - содовые с повышенным содержанием $\mathrm{SO}_{4}{ }^{2-}$ (II подтип) и более высоким значением $\mathrm{pH}(>9)$, если при этом не достигается равновесие по гипсу и другим сульфатным минералам, превалирует окислительная обстановка (сульфатредукция проявлено слабо), а испарение остается незначительным. Очевидно, что 
в последнем случае потребуется растворить значительно больший объем алюмосиликатных пород, в результате чего вода обогатится в большей степени ${ }^{18} \mathrm{O}$, чем содовых I и III подтипов и тем более сульфатных.

Наши исследования показывают, что в озерах идет не только испарение воды, но и продолжается взаимодействие с горными породами. Однако степень такого взаимодействия для каждого типа природных вод разная. При этом испарение для пресных и содовых озер хоть и имеет место быть, но масштаб его по сравнению хлоридными и сульфатными озерами меньше, особенно на начальных стадиях осолонения водоема. Отсюда растет значение $\mathrm{pH}$, накапливаются карбонаты и многие химические элементы, изотопно-тяжелей становиться вода и формируемые карбонаты и алюмосиликаты донных отложений. Напротив, если масштаб взаимодействия воды с породой небольшой, а испарение велико, содержание карбонатных ионов в озере не растет из-за осаждения карбонатов в донные осадки, рН воды уменьшается [Жеребцова, Волкова, 1966; McСaffrey et. all, 1987; Куриленко, 1997 и др.], изотопный состав формируется в большей степени за счет испарения что отмечается для хлоридных озер.

Касаемо углерода, то вариации изотопных соотношений будут определяться внутриводоемными процессами, протекающими в озерах. В хлоридных и сульфатных озерах основная масса растворенных карбонатов высажена в донные осадки, поэтому доля углерода растворенных карбонатов, образующегося за счет деструкции продуцируемого органического С, в общей сумме их выше, чем в содовых. Поскольку на терминальных этапах деструкции не весь восстановленный (органический) углерод минерализуется, переходит в окисленную карбонатную форму, часть его захороняется в донных осадках, то многократно повторяющиеся годовые циклы, в конечном счете приводят к уменьшению доли формирующихся за счет «первичного» биогенного $\mathrm{CO}_{2}$ карбонатных компонентов, поэтому изотопный состав углерода по мере накопления карбонатов утяжеляется, что наблюдается в случае содовых озер.

\section{ВЫВОДЫ}

В близких ландшафтно-климатических и геолого-геохимических условиях формируются разнообразные по составу, солености и морфометрическим характеристикам озера. Климат района исследований определяет высокую степень их испарения. Проведенный расчет по соотношению значений изотопов вод, участвующих в водном питании озер и самих озерах показал, что максимальное значение степени испарения 
характерно для хлоридных озер, в меньшей степени - для сульфатных и минимально - для содовых озер.

На фактическом материале установлено, что наряду с испарением в формировании состава озер участвуют процессы взаимодействия воды с вмещающими породами. Термодинамическими расчетами показано, что со многими минералами магматических пород основного состава все озерные воды не равновесны. С алюмосиликатными минералами кислых и средних пород равновесие наступает только при относительно высокой минерализации и рН озерных вод.

Непрерывное растворение одних минералов и осаждение других приводит к изменению соотношения тяжелых изотопов воды, участвующей в этих реакциях с обогащением изотопом ${ }^{18} \mathrm{O}$ не только вторичных минералов, но и воды. Наличие в содовых озерах среди вторичных алюмосиликатов большего числа минералов обычно гидротермального генезиса, более высоких концентраций многих микроэлементов и значений $\mathrm{pH}$ является подтверждением тому, что время взаимодействия с породами донных отложений и прибрежной части для них больше, чем хлоридных и сульфатных. Отсюда вода, гидро- и карбонатные ионы, алюмосиликатная и карбонатная фракции донных осадков, бактериальные маты содовых озер в большей степени обогащены тяжелым изотопом кислорода.

Близкая картина характерна и для фракционирования изотопов углерода растворенных карбонатов. При окислении в $\mathrm{CO}_{2}$, который в дальнейшем по реакции (2) переходит в ионы $\mathrm{HCO}_{3}{ }^{-}$и $\mathrm{CO}_{3}^{2-}$, концентрирующиеся преимущественно в содовых водах. Многократно повторяющиеся циклы минерализации органики и ее образования обеспечивают накопление тяжелого изотопа углерода и в бактериальных матах. Отсюда изотопный состав углерода по мере накопления в озерах гидро- и карбонатных ионов, а в дальнейшем и осажденных в донные осадки карбонатов постепенно утяжеляется.

О разной интенсивности водообмена также свидетельствует наличие связи $\delta^{18} \mathrm{O}-\mathrm{TIC}$ с $\delta^{13} \mathrm{C}$-TIC донных осадков содовых озер и отсутствие таковой в хлоридных и сульфатных, а это значит, что карбонаты первых формируются в условиях относительно стабильного гидрологического режима. Действительно в питании содовых озер принимают участие реки и ручьи, они имеют больший объем воды, чем сульфатные и хлоридные, поэтому в меньшей степени подвержены испарению.

Таким образом, формирование химического состава соленых озер исследуемого региона - многофакторный процесс, в котором наряду с испарительным концентрированием участвуют процессы растворения водой одних минералов и образования других, минерализации органики и окисления сульфидов. Поэтому в каждом 
озере региона имеются продукты всех перечисленных процессов, а именно: $\mathrm{HCO}_{3}{ }^{-}$и $\mathrm{CO}_{3}{ }^{2-}$, $\mathrm{Cl}^{-}, \mathrm{SO}_{4}^{2-}, \mathrm{Na}, \mathrm{Ca}$ и $\mathrm{Mg}$, но их соотношение в разных типах озер неодинаково. В среднем хлориды преобладают не только в хлоридных озерах, что естественно, но и содовых. Все это отражает очевидный факт значительной роли процессов испарения в формировании состава всех озер. Содержание $\mathrm{HCO}_{3}{ }^{-}$и $\mathrm{CO}_{3}{ }^{2-}$ в среднем немного ниже даже в содовых озерах, чем $\mathrm{Cl}^{-}$, но если брать только с низкой соленостью озера, то в них значительно преобладают карбонаты. Иначе говоря, процесс накопления соды на начальных стадиях испарения преобладает над концентрированием хлоридов, но на последних более высоких стадиях, когда переходит в осадок большое количество вторичных минералов, процесс концентрирования воды в результате испарения становится весомее. При наличии сульфидов в горных породах появляются дополнительные источники сульфатов, что

обеспечивает формирование сульфатного типа озер. Очевидно, что доминирование того или иного процесса определяет геохимическое разнообразие соленых озер Восточного Забайкалья.

Исследования выполнены в рамках выполнения государственного задания и частично при финансовой поддержке проекта РФФИ № 18-05-00104.

Авторы статьи благодарят рецензентов за внимательное прочтение работы и за высказанные замечания.

\section{СПИСОК ЛИТЕРАТУРЫ}

Абидуева Е.Ю., Сыренжапова А.С., Намсараев Б.Б. Функционирование микробных сообществ в содово-соленых озерах Онон-Керуленской группы (Забайкалье и СевероВосточная Монголия) // Сибирский экологический журнал. 2006. № 6, с. 707-716.

Борзенко С.В. Геохимия соленых озер Восточного Забайкалья. Дис. ... док. геол.мин. наук. Чита: Федеральное государственное бюджетное учреждение науки Институт природных ресурсов, экологии и криологии Сибирского отделения Российской академии наук, 2018. 271 с.

Борзенко С.В. Изотопный состав вод солёных озёр восточного Забайкалья // Доклады Академии наук, 2019, т. 488 (2), с. 1089-1093 doi: 10.1134/S1028334X190901254.

Борзенко С.В. Основные условия формирования химического состава вод соленых и солоноватых озер Восточного Забайкалья // Геохимия, 2020, т. 65, № 9. с. 1-19

Браун Г. Рентгеновские методы изучения и структуры глинистых минералов. М: Изд-во Мир, 1965, 599 с.

Валяшко М.Г. Классификационные признаки соляных озер. Труды ВНИИГ, 1952, т. 23, с. 3-13.

Вант Гофф Я.Г. Океанические соляные отложения. Л.: Химтеорет, 1936, 345 с.

Галимов Э.М. Геохимия стабильных изотопов углерода. М.: Недра, 1968, 226 с. 
Намсараев Б.Б., Бархутова Д.Д., Данилова Э.В., Бурюхаев С.П., Гармаев Е.Ж., Горленко В.М., Дагурова О.П., Дамбаев В.Б., Зайцева С.В., Замана Л.В., Зякун А.М., Лаврентьева А.В., Намсараев 3.Б., Плюснин А.М., Татаринов А.В., Турунхаев А.В., Хахинов В.В., Цыренова Д.Д., Яловик Л.И. Геохимическая деятельность микроорганизмов гидротерм Байкальской рифтовой зоны. Новосибирск: Академическое изд-во «Гео», 2011.302 c.

Замана Л. В., Борзенко С. В. Гидрохимический режим соленых озер Юго-Восточного Забайкалья // География и природные ресурсы, 2010, т. 31 (4), с. 370-376. doi: 10.1016/j.НРГ.2010.11.011

Замана Л.В., Аскаров Ш.А., Борзенко С.В., Чудаев О.В., Брагин И.В. Изотопы сульфидной и сульфатной серы в азотных термах Баунтовской группы (Байкальская рифтовая зона) // Доклады академии наук, 2010, т. 435, № 3, с. 1-3.

Замана Л.В. Изотопный состав жидкой и твердых фаз воды озера Доронинское (Восточное Забайкалье) в связи с образованием солей на его льду // Успехи современного естествознания, 2014, 9, 101-104.

Захарюк А.Г. Распространение и активность алкалофильных сульфат- и железоредуцирующих бактерий в содовых озерах Забайкалья. Автореф. Дис. ... канд. биол. Наук. Улан-Удэ: Институт общей и экспериментальной биологии, 2010, 22 с.

Итигилова М.Ц., Пронин Н.М., Юргенсон Г.А., Птицын А.Б., Калугин И.А., Дарьин А.В., Решетова С.А., Обязов В.А., Помазкова Н.В., Цыбекмитова Г.Ц., Михеев И.Е., Фалейчик Л.М., Замана Л.В., Субботина В.Н., Корякина Е.А., Куклин А.П., Матафонов П.В., Ташлыкова Н.А., Базарова Б.Б., Соколов А.В. Ивано-Арахлейские озера на рубеже веков (состояние и динамика). Новосибирск: Изд-во СО РАН, 2013. 337 с.

Иванов А.В. Формирование химического состава природных вод Приамурья и Забайкалья: сборник / РАН, Дальневосточное отделение, Тихоокеанского Института географии; Владивосток, 1978, 91 с.

Келлер В. Д. Геохимия литогенеза. Москва: Издательство литературы на иностранных языках, 1963, с. 85-197.

Куриленко В.В. Современные бассейны эвапоритовой седиментации. СПб.: СПбГУ, 1997. 256 с.

Жеребцова И. К., Волкова Н.Н. Экспериментальное исследование поведения микроэлементов в процессе естественного солнечного испарения черноморских вод и рассола озера Сасык-Сиваш // Геохимия, 1966, № 7, с. 832-845.

Курнаков Н.И., Николаев В.И. Соляные равновесия при испарении морской воды // Изв. Инст. физ.-хим. анализа АН СССР, 1930, т. 4 (2), с. 15-23.

Лейн А. Ю. Аутигенное карбонатное образование в океане // Литология и полезные ископаемые, 2004, т. 39 (1), с. 1-30.

Обязов В.А. Пространственно-временная изменчивость атмосферных осадков в Юго-восточном Забайкалье // Известия Русского географического общества, 1996, т. 128 (2), с. 73-80.

Обязов, В.А., Смахтин В.К. Ледовый режим рек Забайкалья в условиях изменяющегося климата // Водные ресурсы, 2014, 41 (3), с. 227-234.

Плюснин А.М., Чернявский М.К., Посохов В.Ф. Условия формирования гидротерм Баргузинского Прибайкалья по данным микроэлементного и изотопного состава // Геохимия, 2008, т. 10, с. 1063-1072.

Посохов Е.В. Происхождение содовых вод в природе. Л.: Гидрометеоиздат, 1969, 153 c.

Сонненфелд П. Рассолы и эвапориты: М.: Мир, 1988, 480 с.

Страхов Н.М. Основы теории литогенеза. ТЛИ. М.: АН СССР, 1962, 551 с.

Толстихин Н.И. Гидрогеология СССР. В 45 т. Т. 21. Читинская область. М.: Недра, 1969, 444 c. 
Солоноватые и соленые озера Забайкалья: гидрохимия, биология / Отв. ред. Б.Б. Намсараев. Улан-Удэ: Изд-во Бурятского госуниверситета, 2009, 340 с.

Ферронский В. И., Поляков В. А. Изотопия гидросферы Земли. М.: научный мир, 2009, 632 c.

Шварцев С. Л. Взаимодействие воды с алюмосиликатными породами: обзор // Геология и геофизика, 1991, т. 32 (12), с. 13-37.

Шварцев С. Л. Гидрогеохимия зоны гипергенеза. // Геохимия, 2000, т. 28 (2), с. 260276.

Чабан Н.Н., Беляков Е.А. Геологическая карта СССР масштаба 1:200000. Серия Восточно-Забайкальская. Лист М-50-ХІІІ. Объяснительная записка. М.: Недра, 1974, 51 с.

Юдович Я.Э., Кетрис М.П. Соотношения изотопов углерода в стратисфере и биосфере: четыре сценария // Биосфера, 2010, т. 2 (2), с. 231-246.

Appelo C.A.J., Postma D. Geochemistry, groundwater and pollution. Balkema, Rotterdam, 1993, 536 p.

Aquilina L., Pauwels H., Genter A., Fouillac C. Water-rock interaction processes in the Triassic sandstone and the granitic basement of the Rhine Graben: geochemical investigation of a geothermal reservoir // Geochimica et Cosmochimica Acta, 1997, № 61, p. 4281-4295

Bethke C., Yeakel S. The Geochemist's Workbench Release 11 - GWB Essentials Guide, 2016. https://www.gwb.com/pdf/GWB11/GWBessentials.

Borzenko S.V., Shvartsev S.L. Chemical composition of salt lakes in East Transbaikalia (Russia) // Applied Geochemistry, 2019, № 103, p. 72-84 DOI: 10.1016/j.apgeochem.2019.02.014

Borzenko S.V., Zamana L.V., Usmanova L.I. Basic formation mechanisms of the Lake Doroninskoye soda water (East Siberia, Russia) // Acta Geochimica, 2018, v. 1 (1), p. 1-11. DOI: $10.1007 / \mathrm{s} 11631-017-0250-7$

Borzenko S.V., Shvartsev S.L. Chemical composition of salt lakes in East Transbaikalia (Russia) // Applied Geochemistry. 2019, v. 103, p. 72-84. DOI: 10.1016/j.apgeochem.2019.02.014.

Borzenko S.V., Drebot V.V., Fedorov I.A. Main conditions of soda-type groundwater formation: south-eastern Transbaikal region (Russia) case study // Applied Geochemistry, 2020, Applied Geochemistry. 2020. v. 123. https://doi.org/10.1016/j.apgeochem.2020.104763.

Brooks R., Gibson J.J., Birks J., Weber M.H., Rodecap K.D., Stoddard J.L. Stable isotope estimates of evaporation: inflow and water residence time for lakes across the United States as a tool for national lake water quality assessments // Limnology Oceanography, 2014, v. 59 (6), p. 2150-2165. doi:10.4319/lo.2014.59.6.2150

Clark I., Fritz, P. Environmental isotopes in hydrogeology. CRC Press, Boca Raton, 1997, f l, 328 p.

Craig H. Isotopic variations in meteoric waters // Science, 1961, № 133, p. 1702-1703.

Dansgaard W. Stable isotopes in precipitation // Tellus, 1964, v. 16 (4), p. 436-468.

Drever. J.I. Surface and groundwater, weathering, and soils: Treatise on geochemistry, 2005, 644 p.

Fontes J. Ch., Gonfiantini R. Component isotopique au cours de l'tvaporation de deux basins sahariens // Earth and Planetary Science Letters, 1967, № 3, p. 58-266

Ga'zquez F., Evans N.P., David A. Hodell F. Precise and accurate isotope fractionation factors $\left(\delta^{17} \mathrm{O}, \quad \delta^{18} \mathrm{O}\right.$ and $\left.\delta \mathrm{D}\right)$ for water and $\mathrm{CaSO}_{4} \cdot 2 \mathrm{H}_{2} \mathrm{O}$ (gypsum) // Geochimica et Cosmochimica Acta, 2017, № 198, p. 259-270.

Gammons C.H., Poulson S.R., Pellicori D.A., Reed P.J., Roesler A.J., Petrescu E.M. The hydrogen and oxygen isotopic composition of precipitation, evaporated mine water, and river water in Montana, USA // Journal Hydrologic, 2006, v. 328 (1), p. 319330, 10.1016/j.jhydrol.2005.12.005 
Gibson J.J., Reid R. Water balance along a chain of tundra lakes: a 20-year isotopic perspective // Journal Hydrologic, 2014, № 519, p. 2148-2164 DOI 10.1016/j.jhydrol.2014.10.011

Good S.P., Mallia D.V., Lin J.C., Bowen G. Stable isotope analysis of precipitation samples obtained via crowdsourcing reveals the spatiotemporal evolution of Superstorm Sandy // PLoS One, 2014, v. 9 (3). Article e91117, 10.1371/journal.pone.0091117

Hardie L.A., Eugster H.P. The evolution of closed basin brines // Mineralogical Society of America, 1970, № 3, p. 273-290.

Harvie C.E., Weare J.H., Hardie L.A., Eugster H.P. Evaporation of sea water: calculated mineral sequences // Science, 1980, № 208, p. 498-500.

Helgeson $\mathrm{H}$. Evaluation of irreversible reactions in geochemical processes involving minerals and aqueous solutions-1.Thermodynamic relations // Geochimica et Cosmochimica Acta, 1968, № 32, p. 853-877

Hesse R., Frape S.K., Egeberg P.K., Matsumoto R. Stable isotope studies (Cl, O, and H) of interstitial waters from site 997, Blake Ridge gas hydrate field, West Atlantic Proc. Ocean Drilling Program, Sci. Results, 2000, № 164, p. 129-137. http://wateriso.utah.edu/waterisotopes/index.html

Holland H.D., Turekian K.K. Isotope geochemistry. Elsevier, Academic Press, 2011, 739 p.

Hubbard C. R., Snyder R. L. RIR - Measurement and Use in Quantitative XRD // Powder Diffraction, 1988, № 3, p. 74-77.

Kharaka Y., Mariner R., Ambats G., Bullen T., Kennedy, B.M. Origins of water and solutes in and north of the Norris-Mammoth Corridor, Yellowstone National Park. Transactions Geothermal Resources Council. 14 (pt 1), 1990. p. 705-714.

Kloppmann, W., Girard J.-P., Negrel P. Exotic isotope compositions of saline waters and brines from the crystalline basement // Chemical Geology, 2002, V. 184 (1-2), p. 49-70.

Kolpakova M.N.; Gaskova, O.L.; Naymushina, O.S.; Karpov A.V., Vladimirov A.G.; Krivonogov S.K. Saline lakes of Northern Kazakhstan: Geochemical correlations of elements and controls on their accumulation in water and bottom sediments // Applied Geochemistry, 2019, v.107, p. 8-18 doi: 10.1016/j.apgeochem.2019.05.013

Matsuo S., Kuroda Y., Suzuoki T. Mantle water based on the hydrogen isotope ratios of hydrouse silicates in the mantel // Geological Survey Open-file Reports, 1978, № 701, p. 278280.

McCaffrey M.A., Lazar B., Holland H.D. The evaporation path of seawater and the coprecipitation of $\mathrm{Br}^{-}$and $\mathrm{K}^{+}$with halite // Journal of Sedimentation Petrology, 1987, № 57, p. 928-937.

Merkel B.J. Groundwater Geochemistry: A Practical Guide to Modeling of Natural and Contaminated Aquatic Systems. Planer-Friedrich; ed. by D.K. Nordstrom. Springer-Verlag Berlin Heidelberg, 2005, 230 p.

Nordstrom D.K., Ball J.W., Donahoe R.J., Whittemore D. Groundwater chemistry and water-rock interactions at Stripa // Geochimica et Cosmochimica Acta, 1989, v. 53 (8), p. 17271740, DOI.org/10.1016/0016-7037(89)90294-9.

Northrop D.A., Clayton R.N. Oxygen isotope fractionation in system containing dolomite // Journal Geology, 1966, № 74, p. 174-196.

O’Heil J.R., Adomi E.H., Epstein S. Revised value for the 180 fractionation between $\mathrm{CO} 2$ and water at $25{ }^{\circ} \mathrm{C}$. // Journal of Research of the U. S. Geological Survey, 1975, № 3, 623624

Paćes T. Rate constants of dissolution derived from the measurements of mass balance in hydrological catchments // Geochimica et Cosmochimica Acta, 1983, v. 47 (11), 1855-1863, DOI.org/10.1016/0016-7037(83)90202-8. 
Pellicori D.A., Gammons C.H., Poulson S.R. Geochemistry and stable isotope composition of the Berkeley pit lake and surrounding mine waters, Butte, Montana // Applied Geochemistry, 2005, v. 20 (11),p. 2116-2137, 10.1016/j.apgeochem.2005.07.010

Sánchez-España F.J., Diez-Ercilla M., Pérez-Cerdán F., Yusta I., Boyce A. Hydrological investigation of a multi-stratified pit lake using radioactive and stable isotopes combined with hydrometric monitoring // Journal Hydrologic, 2014, № 511, p. 494-508.

Savin S.M., Epstein S. The oxygen and hydrogen isotope geochemistry of ocean sediments and shales // Geochimica et Cosmochimica Acta,, 1970a, № 34, p. 43-63.

Savin S.M., Epstein S. The oxygen and hydrogen isotope composition of coarse grained sedimentary rocks and minerals // Geochimica et Cosmochimica Acta, 1970b, № 34, p. 323-329

Scislewski A., Zuddas P. Estimation of reactive mineral surface area during water-rock interaction using fluid chemical data // Geochimica et Cosmochimica Acta, 2010, v. 74 (24), p. 6996-7007, https://doi.org/10.1016/j.gca.2010.09.015.

Seal R.R., Shanks W.C. Oxygen and hydrogen isotope systematics of Lake Baikal, Siberia: Implications for paleoclimate studies // Limnology Oceanography, 1998, v. 43 (6), p. 1251-1261.

Sharp Z.D. A laser-based microanalytical method for the in situ determination of oxygen isotope ratios of silicates and oxides // Geochimica et Cosmochimica Acta, 1990, № 54, p. 13531357.

Sheppard S.M.F., Nielsen R.L., Taylor H.P. Oxygen and hydrogen isotope ratios of clay minerals from porphyry deposits // Economic Geology, 1971, № 66, p. 515-542.

Skrzypek G., Mydłowskic A.,_Dogramaci S., Hedleyd P., Gibsone J.J., Griersonab P.F. Estimation of evaporative loss based on the stable isotope composition of water using Hydrocalculat // Journal Hydrology, 2015, №_ 523, p. 781-789 http://dx.doi.org/10.1016/j.jhydrol.2015.02.010

Sofer Z., Gat J.R. Activities and concentration of oxygen-18 in concentrated aqueous salt solutions: analytical and geophysical implications // Earth and Planetary Science Letters, 1975, № 26, p. 179-186.

Talbot M.R. A review of the palaeohydrological interpretation of carbon and oxygen isotope ratios in primary lacustrine carbonates // Chemical Geology (Isotope Geoscience Section), 1990, № 80, p. 261-279.

Warren J.K. Evaporite Sedimentology // Journal Sedimentology, 1989, v. 29 (5), p. 548556.

Zamana L.V., Borzenko S.V. Isotopic Composition of Dissolved Carbonates Meromictic Soda Lake Doroninskoe (Eastern Transbaikalia, Russia) // Acta Geologica Sinica, 2014, № 88, p. 395-397.

Zheng M. Saline lakes and salt basin deposits in China. Beijing: Science Press, 2014, 321 p.

Zhu Z., Chen J., Zeng Y. Abnormal positive $\delta^{13} \mathrm{C}$ values of carbonate in Lake Caohai, southwest China, and their possible relation to lower temperature // Quaternary International, 2013, № 286, p. 85-93. 


\section{Подрисуночные подписи}

Рис. 1. Схема размещения изученных озер Забайкалья.

Рис. 2. Зависимость значений $\delta \mathrm{D}$ атмосферных осадков (дождь) от координат местности и абсолютной высоты.

Рис. 3. Распределение значений $\delta \mathrm{D}$ и $\delta^{18} \mathrm{O}$ в природных водах региона.

Рис. 4. Связь содержаний растворенного в воде $\mathrm{CO}_{2}$ с $\Delta \delta^{18} \mathrm{O}$ (а) и $\Delta \delta^{18} \mathrm{O}$ с $\mathrm{pH}$ (б).

Рис. 5. Зависимость $\Delta \delta^{18} \mathrm{O}$ (а) и $\mathrm{pH}$ (б) от расстояния области питания до разгрузки подземных вод S.

Рис. 6. Связь солености и рН в разных типах соленых озер.

Рис. 7. Зависимость солености (а) и рН (б) от степени испарения $f$ воды, а также TDIC от рH (с) в выделенных типах и подтипах озер.

Рис. 8. Связь $\delta^{18} \mathrm{O} \mathrm{H}_{2} \mathrm{O}$ с $\delta^{18} \mathrm{O}$-TDIC.

Рис. 9. Связь содержания TDIC с (а), $\delta^{13} \mathrm{C}$-TDIC с $\delta^{13} \mathrm{C}$-TIC и $\delta^{13} \mathrm{C}$-BOC (б), соотношение $\delta^{13} \mathrm{C}$-TIC и $\delta^{18} \mathrm{O}-\mathrm{TIC}($ в) в выделенных типах озер.

Рис. 10. Связь рН с $\Delta \delta^{18} \mathrm{O}$ в выделенных типах природных вод. 
Табл. 1. Координаты, минерализация, $\mathrm{pH}$, химический тип и гидроизотопные данные атмосферных осадков региона

\begin{tabular}{|c|c|c|c|}
\hline \multirow{2}{*}{ Параметры } & Юго-Восток, n=10 & Северо-Запад, n=2 & \multirow{2}{*}{$\begin{array}{c}\text { Юго-Восток, } \mathrm{n}=2 \\
\text { Снег }\end{array}$} \\
\hline & \multicolumn{2}{|c|}{ Дождь } & \\
\hline $\mathrm{H}, \mathrm{M}$ & $\frac{634 \ldots 709}{668}$ & $751 \ldots 905$ & $649 \ldots 687$ \\
\hline $\mathrm{N}$ & $\frac{50.00000^{\circ} \ldots 50.75515^{\circ}}{50.329893^{\circ}}$ & $51.30677^{\circ} \ldots 52.271^{\circ}$ & $50.2454^{\circ} \ldots 50.5616^{\circ}$ \\
\hline E & $\frac{114.5731^{\circ} \ldots 115.6291^{\circ}}{115.03315^{\circ}}$ & $113.014^{\circ} \ldots 114.0689^{\circ}$ & $114.7935^{\circ} \ldots 115.3281^{\circ}$ \\
\hline М, г/л & $\frac{0.02 \ldots 0.04}{0.03}$ & 0.03 & 0.04 \\
\hline $\mathrm{pH}$ & $\frac{5.6 \ldots 6.8}{6.2}$ & $5.3-5.8$ & $5.9 \ldots 6.3$ \\
\hline$\delta^{18} \mathrm{O}_{\text {vsmow, }} \%$ & $\frac{-12.5 . .-10.5}{-11.5}$ & $-12.8 . .-12.7$ & $-16.0 \ldots-18.9$ \\
\hline$\delta \mathrm{D}_{\mathrm{VSMOW}}, \%$ & $\frac{-90 \ldots-72}{-81}$ & $-108 \ldots-104$ & $-136 \ldots-124$ \\
\hline $\begin{array}{l}\text { Химический } \\
\text { тип }\end{array}$ & & $\mathrm{Ca}-\mathrm{HCO}_{3}$ & \\
\hline
\end{tabular}

Н - абсолютная высота, $\mathrm{N}$ и E - координаты местности, n- количество проб, M - минерализация. 
Табл. 2. Координаты и основные физико-химические и изотопные параметры водопроявлений (подземные воды) региона по выделенным типам

\begin{tabular}{|c|c|c|c|c|c|c|}
\hline $\begin{array}{c}\text { Параметр } \\
\text { ы }\end{array}$ & \multicolumn{2}{|l|}{$\mathrm{Ca}-\mathrm{HCO}_{3}$} & \multicolumn{2}{|l|}{$\mathrm{Mg}-\mathrm{HCO}_{3}$} & \multicolumn{2}{|l|}{$\mathrm{Na}-\mathrm{HCO}_{3}$} \\
\hline $\mathrm{H}, \mathrm{M}$ & $\frac{639 \ldots 734}{674}$ & & $\frac{629 \ldots 729}{653}$ & & $\frac{604 \ldots 745}{640}$ & \\
\hline $\mathrm{N}$ & $\frac{50.261^{\circ} \ldots 50.93896^{\circ}}{50.61678^{\circ}}$ & $n=13$ & $\frac{50.14331^{\circ} \ldots 50.7218^{\circ}}{50.33504^{\circ}} \underline{5}$ & $\mathrm{n}=12$ & $\frac{49.95687^{\circ} .50 .72856^{\circ}}{50.25611^{\circ}}$ & $\mathrm{n}=27$ \\
\hline $\mathrm{E}$ & $\frac{114.7928^{\circ} \ldots}{\frac{115.852^{\circ} 9}{115.0255^{\circ}}}$ & & $\frac{114.9732^{\circ} \ldots 116.7198^{\circ}}{115.5881^{\circ}}$ & & $\frac{115.012^{\circ} \ldots 117.054^{\circ}}{115.6747^{\circ}}$ & \\
\hline h, $\mathrm{M}$ & $\frac{20 \ldots 4}{17}$ & $\mathrm{n}=7$ & $\frac{38 \ldots 10}{15}$ & & $\frac{45 \ldots 2}{15}$ & $\mathrm{n}=20$ \\
\hline $\mathrm{D}, \pi / \mathrm{c}$ & $\frac{0.8 \ldots 1.9}{0.9}$ & $n=6$ & $\frac{0.6 \ldots 1.0}{0.7}$ & $n=6$ & $\frac{0.002 \ldots 0.8}{0.5}$ & $n=6$ \\
\hline $\mathrm{T}^{\circ} \mathrm{C}$ & $\frac{2-7}{3}$ & & $\frac{2-11}{4}$ & & $\frac{2-19}{4}$ & \\
\hline $\mathrm{S}^{*}, \mathrm{kм}$ & $\frac{3 \ldots 17}{8}$ & & $\frac{10 \ldots 18}{13}$ & & $\frac{3 \ldots 25}{15}$ & \\
\hline М, г/л & $\frac{0.10 \ldots 2.80}{0.50}$ & $n=13$ & $\frac{0.30 \ldots 2.50}{0.68}$ & $n=12$ & $\frac{0.50 \ldots 3.70}{1.15}$ & $n=28$ \\
\hline $\mathrm{pH}$ & $\frac{6.9 \ldots 8.0}{7.5}$ & & $\frac{6.9 \ldots 8.6}{7.8}$ & & $\frac{6.9 \ldots 9.2}{8.2}$ & \\
\hline $\mathrm{CO}_{2}$, & $\underline{5.1 \ldots 860}$ & & $\underline{1.8 \ldots 120.4}$ & & $\leq 0.4 \ldots 7.4$ & \\
\hline мг/л & 88.3 & & 18.0 & & 8.4 & \\
\hline$\delta^{18} \mathrm{O}_{\text {VSMO }}$ & $-13.8 \ldots-8.9$ & & $-13.1 \ldots-11.4$ & & $-13.9 \ldots-9.5$ & \\
\hline w, \%o & -12.2 & & -12.0 & & -12.1 & \\
\hline $\begin{array}{l}\delta D_{\text {VSMOW }} \\
\% \text { o }\end{array}$ & $\frac{-101 \ldots-70}{-90}$ & $\mathrm{n}=12$ & $\frac{-103 \ldots-91}{-96}$ & & $\frac{-108 \ldots-84}{-94}$ & $\mathrm{n}=26$ \\
\hline$\Delta \delta^{18} \mathrm{O}, \%$ & $\frac{-1.1 \ldots 2.2}{0.2}$ & & $\frac{-0.9 \ldots 2.9}{0.9}$ & $\mathrm{n}=9$ & $\frac{-0.5 \ldots 2.6}{0.9}$ & \\
\hline$\delta^{13} \mathrm{C}_{\mathrm{PDB}}$ & $\frac{-13.7 \ldots 1.1}{-9.7}$ & & $\frac{-12.3 \ldots-9.1}{108}$ & & $\frac{-13.8 \ldots-1.6}{0.1}$ & \\
\hline $\begin{array}{l}\delta^{18} \mathrm{O}_{\text {vSMO }} \\
\text { w, \%o }\end{array}$ & $\frac{16.4 \ldots 24.3}{19.6}$ & $n=9$ & $\frac{18.1 \ldots 21.5}{19.5}$ & & $\frac{17.1 \ldots .23 .4}{19.6}$ & $\mathrm{n}=12$ \\
\hline
\end{tabular}

Н - абсолютная высота, $\mathrm{N}$ и E - координаты, h - уровень воды в скважине, Д- дебит родников, S* расстояние от области питания до разгрузки , $\mathrm{M}$ - минерализация воды, n- количество проб. 
Табл. 3. Координаты и основные физико-химические параметры рек региона по выделенным типам

\begin{tabular}{|c|c|c|c|}
\hline \multicolumn{2}{|l|}{ Параметры } & Са- $-\mathrm{HCO}_{3}$ и Са-SO & $\mathrm{Na}-\mathrm{Cl}$ \\
\hline \multirow{2}{*}{ Координаты } & $\mathrm{N}$ & $52.20554^{\circ} \ldots . .50 .32002^{\circ}$ & $50.26426^{\circ}$ \\
\hline & $\mathrm{E}$ & $112.51100^{\circ} \ldots 115.1067^{\circ}$ & $116.2219^{\circ}$ \\
\hline \multicolumn{2}{|c|}{ Абсолютная высота Н, м } & $635 \ldots 972$ & 587 \\
\hline \multicolumn{2}{|c|}{ Модуль стока, л/с км² } & $\frac{0.2 \ldots 1.2}{0.8}$ & 0.003 \\
\hline \multicolumn{2}{|c|}{ Минерализация, г/л } & $\frac{0.1 . .0 .6}{0.2}$ & 5.0 \\
\hline \multicolumn{2}{|l|}{$\mathrm{pH}$} & $\frac{7.2 \ldots 7.9}{7.5}$ & 7.9 \\
\hline \multicolumn{2}{|l|}{$\delta^{18} \mathrm{O}_{\text {vsmow, }}$ \% } & $\frac{-13.3 \ldots-10.4}{-12.3}$ & -7.1 \\
\hline \multicolumn{2}{|l|}{$\delta \mathrm{D}_{\text {vsmow, }} \%$} & $\frac{-102 \ldots-82}{-96}$ & -69 \\
\hline \multicolumn{2}{|l|}{$\Delta \delta^{18} \mathrm{O}, \%$} & $\frac{-1.1 \ldots 1.8}{-0.4}$ & -1.2 \\
\hline
\end{tabular}


Табл. 4. Координаты и основные параметры озер региона по выделенным типам и подтипам

\begin{tabular}{|c|c|c|c|c|c|c|c|c|c|c|c|}
\hline \multicolumn{2}{|c|}{ Координаты } & \multirow{2}{*}{$\mathrm{H}$} & \multirow{2}{*}{$\mathrm{V}$} & \multirow{2}{*}{ M } & \multirow{2}{*}{$\mathrm{pH}$} & \multirow{2}{*}{$\delta^{18} \mathrm{O}-\mathrm{H}_{2} \mathrm{O}$} & \multirow{2}{*}{$\delta \mathrm{D}-\mathrm{H}_{2} \mathrm{O}$} & \multirow{2}{*}{$\Delta \delta^{18} \mathrm{O}$} & \multirow{2}{*}{$f$} & \multirow{2}{*}{$\delta^{13} \mathrm{C}$-TDIC } & \multirow{2}{*}{$\delta^{18} \mathrm{O}-\mathrm{TDIC}$} \\
\hline $\mathrm{N}$ & $\mathrm{E}$ & & & & & & & & & & \\
\hline \multicolumn{2}{|c|}{ o } & M & $\mathrm{KM}^{3}$ & г/л & - & & $\%$ & & - & $\%$ & \\
\hline \multicolumn{10}{|c|}{ Хлоридный тип Na-Cl, S>1 g/L, pH<9, n=10 } & \multicolumn{2}{|c|}{$\mathrm{n}=14$} \\
\hline $50.2971^{\circ} \ldots 50.71085^{\circ}$ & $114.5923^{\circ} \ldots 116.4576^{\circ}$ & $\begin{array}{c}620 \ldots \\
710\end{array}$ & $\frac{0.00003 \ldots}{\underline{0.003}}$ & $\frac{2.0 \ldots 185}{40.0}$ & $\frac{7.5 \ldots 8.8}{8.3}$ & $\frac{-6.2 \ldots 2.0}{-2.3}$ & $\frac{-68 \ldots-23}{-43}$ & $\frac{-1.5 \ldots}{\frac{1.5}{-0.2}}$ & $\frac{0.23 \ldots 0.70}{0.55}$ & $\frac{-12.5 \ldots 0.8}{-6.3}$ & $\frac{25.8 \ldots 28.7}{27.0}$ \\
\hline \multicolumn{10}{|c|}{ Сульфатный тип Na-SO 4 , S>1 g/L, pH<9, n=5 } & \multicolumn{2}{|c|}{$\mathrm{n}=3$} \\
\hline $49.9304^{\circ} \ldots 51.94836^{\circ}$ & $112.5569^{\circ} \ldots .117 .8659^{\circ}$ & $\begin{array}{c}644 \ldots \\
944\end{array}$ & $\frac{0.0006 \ldots 0.03}{0.003}$ & $\frac{1.8 \ldots 16.9}{5.6}$ & $\frac{7.6 \ldots 8.9}{8.4}$ & $\frac{-8.7 \ldots 1.4}{-3.7}$ & $\frac{-73 \ldots-32}{-49}$ & $\frac{-1.4 \ldots}{\frac{1.4}{-0.3}}$ & $\frac{0.20 \ldots 0.55}{0.41}$ & $\frac{-7.1 . .-4.5}{-6.1}$ & $\frac{26.1 . .27 .4}{26.9}$ \\
\hline \multicolumn{10}{|c|}{ Содовый тип III Na-Cl, n=53 } & \multicolumn{2}{|c|}{$\mathrm{n}=61$} \\
\hline $49.8567^{\circ} \ldots 50.73223^{\circ}$ & $114.5466^{\circ} \ldots 117.8495^{\circ}$ & $\begin{array}{c}585 \ldots \\
676\end{array}$ & $\frac{0.0002 \ldots 0.069}{0.02}$ & $\frac{1.7 \ldots 343}{27.2}$ & $\frac{8.9 \ldots}{\frac{10.0}{9.5}}$ & $\frac{-13.1 \ldots 2.1}{-4.1}$ & $\frac{-108 \ldots-}{\underline{28}}$ & $\frac{-0.7 \ldots}{\frac{4.4}{0.8}}$ & $\frac{0.001 \ldots}{\underline{0.63}}$ & $\frac{-15.8 . .5 .1}{-2.7}$ & $\frac{16.9 . .31 .9}{25.7}$ \\
\hline \multicolumn{10}{|c|}{ Содовый тип II Na-SO4, n=7 } & \multicolumn{2}{|c|}{$\mathrm{n}=8$} \\
\hline $49.9069^{\circ} \ldots 50.8843^{\circ}$ & $114.8226^{\circ} \ldots 117.0734^{\circ}$ & $\begin{array}{c}640 \ldots \\
747\end{array}$ & $\frac{0.0001 \ldots 0.04}{0.01}$ & $\frac{5.4 \ldots 54.3}{21.6}$ & $\frac{9.1 \ldots 9.7}{9.4}$ & $\frac{-5.4 \ldots 0.5}{-2.0}$ & $\frac{-57 \ldots-38}{-46}$ & $\frac{-0.1 \ldots}{\frac{3.7}{1.1}}$ & $\frac{0.30 \ldots 0.49}{0.38}$ & $\frac{-12.0 \ldots 3.5}{-2.8}$ & $\frac{20.8 \ldots 30.9}{26.3}$ \\
\hline \multicolumn{10}{|c|}{ Содовый тип Іподтип $\mathrm{Na}-\mathrm{HCO}_{3}+\mathrm{CO}_{3}, \mathrm{n}=13$} & \multicolumn{2}{|c|}{$\mathrm{n}=22$} \\
\hline $\begin{array}{c}50.16531^{\circ} \ldots \\
51.43981^{\circ}\end{array}$ & $111.72445^{\circ} \ldots 115.6578^{\circ}$ & $\begin{array}{c}615 \ldots \\
745\end{array}$ & $\frac{0.0006 \ldots 2.08}{0.03}$ & $\frac{1.2 \ldots}{\frac{80.7}{14.0}}$ & $\frac{9.0 \ldots 9.9}{9.3}$ & $\frac{-10.7 \ldots 1.8}{-4.0}$ & $\frac{-83 \ldots-30}{-51}$ & $\frac{-0.8 \ldots}{\frac{2.1}{0.5}}$ & $\frac{0.10 \ldots 0.61}{0.37}$ & $\frac{-8.1 . .1 .1}{-2.2}$ & $\frac{21.9 . .39 .9}{26.9}$ \\
\hline \multicolumn{9}{|c|}{ Пресные озера $\mathrm{Na}-\mathrm{HCO}_{3} \mathrm{n}=11$} & $\mathrm{E} / \mathrm{I}$ & \multicolumn{2}{|c|}{$\mathrm{n}=4$} \\
\hline $50.35038^{\circ} \ldots 52.31159^{\circ}$ & $112.2562^{\circ} \ldots 115.6023^{\circ}$ & $\begin{array}{c}610 \ldots \\
984\end{array}$ & $\frac{0.006 \ldots 0.2}{0.04}$ & $\frac{0.1 \ldots 0.9}{0.5}$ & $\frac{7.2 \ldots 8.9}{8.1}$ & $\frac{-11.8 \ldots-0.2}{-6.9}$ & $\frac{-88 \ldots-38}{-68}$ & $\frac{-1.4 \ldots}{\frac{0.7}{0.1}}$ & $\frac{0.31-0.82}{0.38}$ & $\frac{-11.3 \ldots-2.9}{-6.5}$ & $\frac{21.4 \ldots 29.2}{26.0}$ \\
\hline \multicolumn{10}{|c|}{ Пресные озера Са-НСО 3 n=11 } & \multicolumn{2}{|c|}{$\mathrm{n}=6$} \\
\hline $\begin{array}{c}50.70349^{\circ} \ldots \\
52.31813^{\circ}\end{array}$ & $112.5001^{\circ} \ldots 115.20811^{\circ}$ & $\begin{array}{c}661 \ldots \\
972\end{array}$ & $\frac{0.05-0.6}{0.08}$ & $\frac{0.1 \ldots 0.7}{0.3}$ & $\frac{7.3 \ldots 8.1}{7.7}$ & $\frac{-11.5 \ldots-5.3}{-7.7}$ & $\frac{-84 \ldots-61}{-72}$ & $\frac{-0.5 \ldots}{\underline{1.8}}$ & $\frac{0.11-1.02}{0.18}$ & $\frac{-14.8 \ldots 0.6}{-6.7}$ & $\frac{22.5 \ldots 25.9}{24.4}$ \\
\hline
\end{tabular}

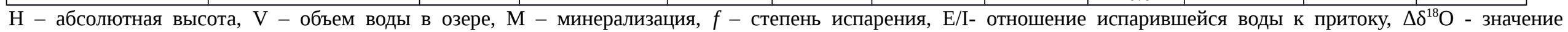
«кислородного сдвига», n - кол-во проб. 
Табл. 5. Основные химические показатели озер Восточного Забайкалья по выделенным типам и подтипам

\begin{tabular}{|c|c|c|c|c|c|c|c|c|c|}
\hline \multirow[b]{2}{*}{ Параметры } & \multicolumn{3}{|c|}{ Пресные } & \multicolumn{4}{|c|}{ Содовый тип } & \multirow[b]{2}{*}{$\begin{array}{c}\text { Сульфатный тип, } \\
\text { n=5 }\end{array}$} & \multirow[b]{2}{*}{$\begin{array}{c}\text { Хлоридный тип, } \\
\text { n=14 }\end{array}$} \\
\hline & $\begin{array}{c}\text { Среднее, } \\
\text { n=22 }\end{array}$ & $\begin{array}{c}\mathrm{Ca}-\mathrm{HCO}_{3}, \\
\mathrm{n}=11\end{array}$ & $\begin{array}{c}\mathrm{Na}-\mathrm{HCO}_{3}, \\
\mathrm{n}=11\end{array}$ & $\begin{array}{c}\text { Среднее, } \\
\text { n=106 }\end{array}$ & $\begin{array}{c}\text { I подтип, } \\
\text { n=37 }\end{array}$ & $\begin{array}{c}\text { II подтип, } \\
\text { n=8 }\end{array}$ & $\begin{array}{c}\text { III подтип, } \\
\text { n=61 }\end{array}$ & & \\
\hline Eh, мB & $\frac{-100-320}{258}$ & $\frac{-50-320}{265}$ & $\frac{-100-250}{256}$ & $\frac{-423-281}{75}$ & $\frac{-423-281}{75}$ & $\frac{45-155}{86}$ & $\frac{-125-265}{73}$ & $\frac{104-180}{120}$ & $\frac{-10-98}{53}$ \\
\hline $\mathrm{CO}_{2}$, мг/л & $\frac{<0.4-34.8}{12.8}$ & $\frac{<0.4-34.8}{14.8}$ & $\frac{\leq 0.4-24.2}{5.6}$ & $<0.4$ & $<0.4$ & $<0.4$ & $<0.4$ & $<0.4$ & $\frac{132.0-156.0}{144.0}$ \\
\hline $\begin{array}{l}\mathrm{CO}_{3}{ }^{2-} \\
+\mathrm{HCO}_{3}^{-}, \text {г/л }\end{array}$ & $\frac{0.09-0.55}{0.25}$ & $\frac{0.06-0.31}{0.26}$ & $\frac{0.33-0.55}{0.42}$ & $\frac{0.05-30.0}{3.10}$ & $\frac{0.42-30.0}{3.50}$ & $\frac{0.63-17.0}{4.30}$ & $\frac{0.24-22.0}{2.90}$ & $\frac{0.07-1.80}{0.81}$ & $\frac{0.06-2.10}{0.50}$ \\
\hline $\mathrm{SO}_{4}^{2-}$, г/л & $\frac{0.001-0.16}{0.025}$ & $\frac{0.001-0.16}{0.021}$ & $\frac{0.01-0.08}{0.35}$ & $\frac{0.01-62.0}{2.20}$ & $\frac{0.01-2.00}{0.59}$ & $\frac{1.70-13.8}{6.20}$ & $\frac{0.06-62.0}{3.10}$ & $\frac{0.49-7.60}{2.90}$ & $\frac{0.21-14.0}{3.50}$ \\
\hline $\mathrm{Cl}^{-}$, г/л & $\frac{0.004-0.21}{0.026}$ & $\frac{0.002-0.019}{0.009}$ & $\frac{0.015-0.21}{0.08}$ & $\frac{0.03-134.0}{4.20}$ & $\frac{0.03-14.0}{1.40}$ & $\frac{0.32-6.60}{2.70}$ & $\frac{0.39-134.0}{7.20}$ & $\frac{0.27-2.10}{0.90}$ & $\frac{1.20-101.0}{17.80}$ \\
\hline $\mathrm{F}^{-}$, г/л & $\frac{0.0001-0.0077}{0.0013}$ & $\frac{0.001-0.002}{0.004}$ & $\frac{0.0002-}{\frac{0.007}{0.004}}$ & $\frac{0.001-0.410}{0.010}$ & $\frac{0.001-0.070}{0.010}$ & $\frac{0.001-0.110}{0.020}$ & $\frac{0.001-0.410}{0.020}$ & $\frac{0.001-0.005}{0.002}$ & $\frac{0.001-0.040}{0.007}$ \\
\hline $\mathrm{Ca}^{2+}$, г/л & $\frac{0.016-0.053}{0.029}$ & $\frac{0.009-0.053}{0.027}$ & $\frac{0.019-0.046}{32.1}$ & $\frac{0.001-0.080}{0.020}$ & $\frac{0.001-0.060}{0.020}$ & $\frac{0.003-0.020}{0.008}$ & $\frac{0.001-0.080}{0.010}$ & $\frac{0.005-0.080}{0.050}$ & $\frac{0.006-0.620}{0.100}$ \\
\hline $\mathrm{Mg}^{2+}$, г/л & $\frac{0.004-0.059}{0.015}$ & $\frac{0.004-0.025}{0.010}$ & $\frac{0.015-0.060}{29.9}$ & $\frac{0.001-0.400}{0.070}$ & $\frac{0.003-0.180}{0.060}$ & $\frac{0.050-0.380}{0.210}$ & $\frac{0.001-0.400}{0.050}$ & $\frac{0.030-0.090}{0.060}$ & $\frac{0.010-3.800}{0.620}$ \\
\hline $\mathrm{Na}^{+}$, г/л & $\frac{0.006-0.211}{0.047}$ & $\frac{0.006-0.062}{0.020}$ & $\frac{0.073-0.21}{0.13}$ & $\frac{0.27-125.0}{5.10}$ & $\frac{0.27-19.0}{2.40}$ & $\frac{1.40-17.0}{5.80}$ & $\frac{0.37-125.0}{7.40}$ & $\frac{0.39-5.40}{2.20}$ & $\frac{1.35-65.0}{13.00}$ \\
\hline $\mathrm{K}^{+}$, г/л & $\frac{0.001-0.017}{0.006}$ & $\frac{0.003-0.016}{0.004}$ & $\frac{0.004-0.017}{0.010}$ & 0.060 & $\frac{0.003-0.440}{0.050}$ & $\frac{0.050-0.360}{0.160}$ & $\frac{0.002-0.200}{0.060}$ & $\frac{0.010-0.040}{0.020}$ & $\frac{0.010-0.240}{0.080}$ \\
\hline $\mathrm{Si}$, мг/л & $\frac{0.5-75.0}{2.1}$ & $\frac{0.5-6.0}{2.3}$ & $\frac{0.5-7.5}{2.8}$ & $\frac{2.3-22.0}{5.5}$ & $\frac{3.6-22.0}{6.4}$ & $\frac{4.5-6.8}{5.9}$ & $\frac{2.3-10.0}{4.8}$ & $\frac{2.9-4.1}{3.6}$ & $\frac{3.4-4.5}{3.6}$ \\
\hline $\mathrm{Al}, \mathrm{мкг/л}$ & $\frac{0.008-0.55}{0.058}$ & $\frac{7.8-41.2}{20.0}$ & $\frac{21.4-552}{196}$ & $\frac{0.01-17.0}{0.35}$ & $\frac{0.01-3.50}{0.17}$ & $\frac{0.01-2.10}{0.38}$ & $\frac{0.01-17.0}{0.50}$ & $\frac{0.07-0.40}{0.20}$ & $\frac{0.02-0.42}{0.13}$ \\
\hline REE, мкг/л & $\frac{0.8-5.4}{0.68}$ & $\frac{0.01-0.45}{0.23}$ & $\frac{0.93-5.4}{2.3}$ & $\frac{0.4-109.0}{8.3}$ & $\frac{0.4-56.0}{2.2}$ & $\frac{0.1-109.0}{20.0}$ & $\frac{0.4-82.0}{2.8}$ & $\frac{0.8-1.0}{0.9}$ & $\frac{0.1-2.5}{0.7}$ \\
\hline Zr, мкг/л & $\frac{0.02-0.33}{0.12}$ & $\frac{0.02-0.16}{0.08}$ & $\frac{0.2-0.33}{0.25}$ & $\frac{0.1-1104.0}{50.0}$ & $\frac{0.4-935.0}{50.0}$ & $\frac{0.1-677.0}{115.0}$ & $\frac{0.3-1104.0}{60.0}$ & $\frac{0.7-4.5}{2.0}$ & $\frac{0.1-48.0}{7.8}$ \\
\hline Мо, мкг/л & $\frac{1.87-9.2}{4.8}$ & $\frac{1.87-8.34}{3.94}$ & $\frac{5.30-9.24}{7.46}$ & $\frac{0.003-3.00}{0.12}$ & $\frac{0.003-0.54}{0.06}$ & $\frac{0.013-3.00}{0.78}$ & $\frac{0.01-0.92}{0.09}$ & $\frac{0.02-0.16}{0.07}$ & $\frac{0.02-0.38}{0.09}$ \\
\hline
\end{tabular}

n- количество проб, * min- max/ mean. 
Табл. 7. Состав минералов донных осадков озер, их изотопные соотношения $\delta^{18} \mathrm{O}-\mathrm{SiO}_{2}$ и $\delta^{18} \mathrm{O}-$ и $\delta^{13} \mathrm{C}$-TIC, также $\delta^{18} \mathrm{O}-$ и $\delta^{13} \mathrm{C}-\mathrm{BOC}$ (\%) бактериальных матов в выделенных типах и подтипах озер региона

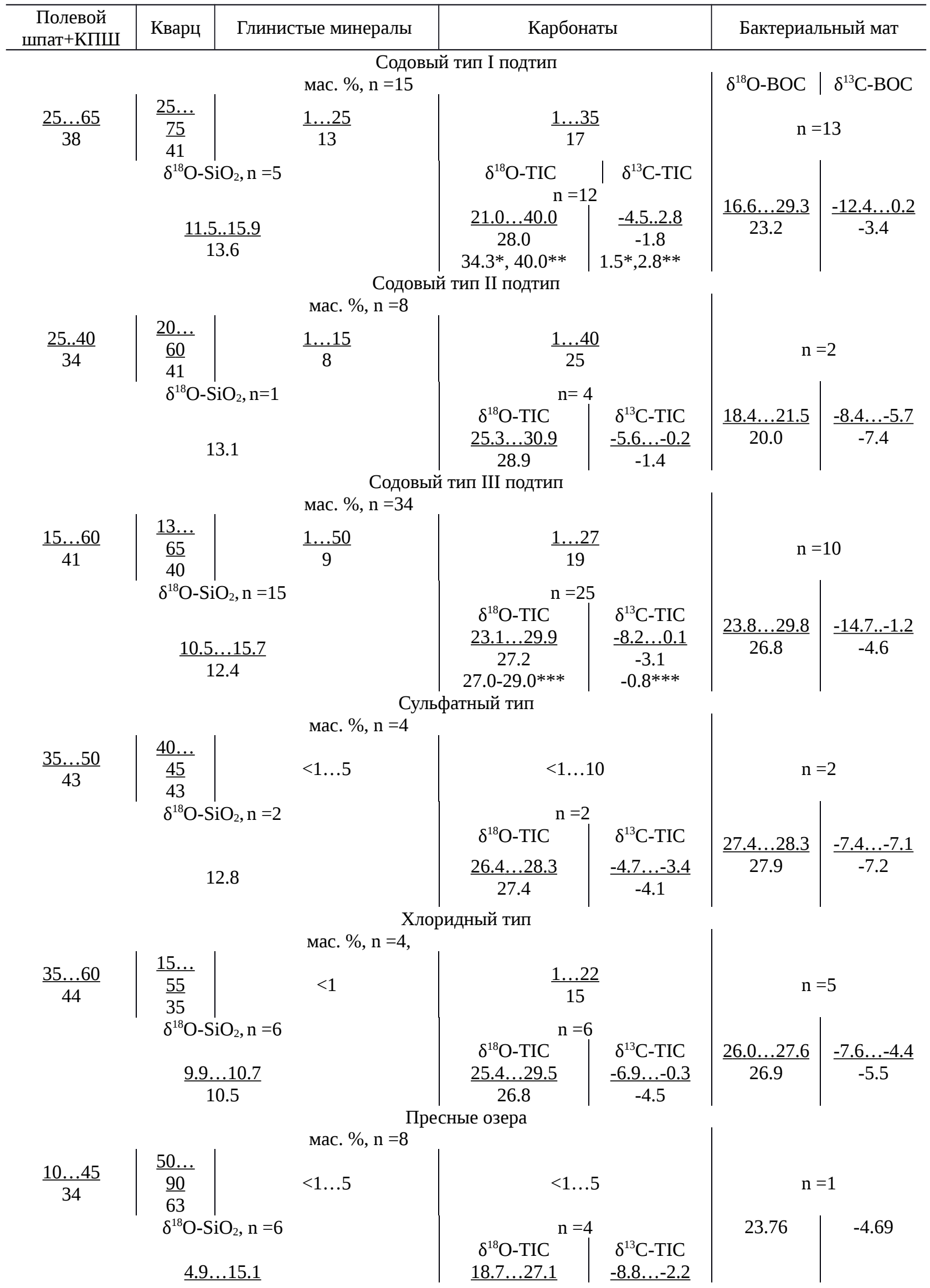


8.1

23.7

- данные отсутствуют, * гейлюссит (n=1), ** сода и трона $(\mathrm{n}=1)$, *** доломит $(\mathrm{n}=3)$. 
Табл. 8. Необходимые геохимические параметры для формирования определенного вторичного минерала (содержание макрокомпонентов и соленость даны в г/л, Si - мг/л)

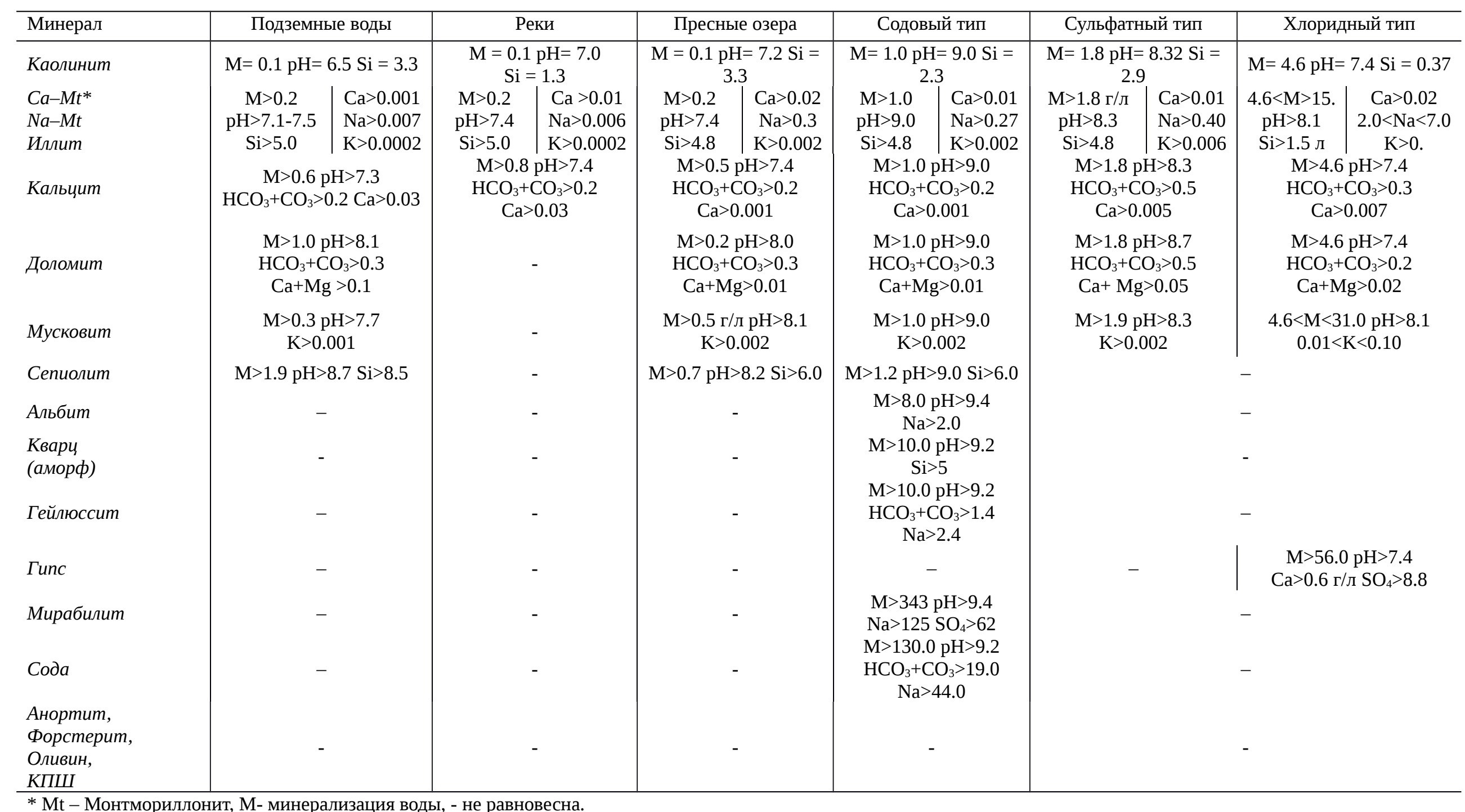


Табл. 5. Основные химические показатели озер Восточного Забайкалья по выделенным типам и подтипам

\begin{tabular}{|c|c|c|c|c|c|c|c|c|c|}
\hline \multirow[b]{2}{*}{ Параметры } & \multicolumn{3}{|c|}{ Пресные } & \multicolumn{4}{|c|}{ Содовый тип } & \multirow[b]{2}{*}{$\begin{array}{c}\text { Сульфатный тип, } \\
\text { n=5 }\end{array}$} & \multirow[b]{2}{*}{$\begin{array}{c}\text { Хлоридный тип, } \\
\text { n=14 }\end{array}$} \\
\hline & $\begin{array}{c}\text { Среднее, } \\
\text { n=22 }\end{array}$ & $\begin{array}{c}\mathrm{Ca}-\mathrm{HCO}_{3}, \\
\mathrm{n}=11\end{array}$ & $\begin{array}{c}\mathrm{Na}-\mathrm{HCO}_{3}, \\
\mathrm{n}=11\end{array}$ & $\begin{array}{c}\text { Среднее, } \\
\text { n=106 }\end{array}$ & $\begin{array}{c}\text { I подтип, } \\
\text { n=37 }\end{array}$ & $\begin{array}{c}\text { II подтип, } \\
\text { n=8 }\end{array}$ & $\begin{array}{c}\text { III подтип, } \\
\text { n=61 }\end{array}$ & & \\
\hline Eh, мB & $\frac{-100-320}{258}$ & $\frac{-50-320}{265}$ & $\frac{-100-250}{256}$ & $\frac{-423-281}{75}$ & $\frac{-423-281}{75}$ & $\frac{45-155}{86}$ & $\frac{-125-265}{73}$ & $\frac{104-180}{120}$ & $\frac{-10-98}{53}$ \\
\hline $\mathrm{CO}_{2}$, мг/л & $\frac{<0.4-34.8}{12.8}$ & $\frac{<0.4-34.8}{14.8}$ & $\frac{\leq 0.4-24.2}{5.6}$ & $<0.4$ & $<0.4$ & $<0.4$ & $<0.4$ & $<0.4$ & $\frac{132.0-156.0}{144.0}$ \\
\hline $\begin{array}{l}\mathrm{CO}_{3}{ }^{2-} \\
+\mathrm{HCO}_{3}^{-}, \text {г/л }\end{array}$ & $\frac{0.09-0.55}{0.25}$ & $\frac{0.06-0.31}{0.26}$ & $\frac{0.33-0.55}{0.42}$ & $\frac{0.05-30.0}{3.10}$ & $\frac{0.42-30.0}{3.50}$ & $\frac{0.63-17.0}{4.30}$ & $\frac{0.24-22.0}{2.90}$ & $\frac{0.07-1.80}{0.81}$ & $\frac{0.06-2.10}{0.50}$ \\
\hline $\mathrm{SO}_{4}^{2-}$, г/л & $\frac{0.001-0.16}{0.025}$ & $\frac{0.001-0.16}{0.021}$ & $\frac{0.01-0.08}{0.35}$ & $\frac{0.01-62.0}{2.20}$ & $\frac{0.01-2.00}{0.59}$ & $\frac{1.70-13.8}{6.20}$ & $\frac{0.06-62.0}{3.10}$ & $\frac{0.49-7.60}{2.90}$ & $\frac{0.21-14.0}{3.50}$ \\
\hline $\mathrm{Cl}^{-}$, г/л & $\frac{0.004-0.21}{0.026}$ & $\frac{0.002-0.019}{0.009}$ & $\frac{0.015-0.21}{0.08}$ & $\frac{0.03-134.0}{4.20}$ & $\frac{0.03-14.0}{1.40}$ & $\frac{0.32-6.60}{2.70}$ & $\frac{0.39-134.0}{7.20}$ & $\frac{0.27-2.10}{0.90}$ & $\frac{1.20-101.0}{17.80}$ \\
\hline $\mathrm{F}^{-}$, г/л & $\frac{0.0001-0.0077}{0.0013}$ & $\frac{0.001-0.002}{0.004}$ & $\frac{0.0002-}{\frac{0.007}{0.004}}$ & $\frac{0.001-0.410}{0.010}$ & $\frac{0.001-0.070}{0.010}$ & $\frac{0.001-0.110}{0.020}$ & $\frac{0.001-0.410}{0.020}$ & $\frac{0.001-0.005}{0.002}$ & $\frac{0.001-0.040}{0.007}$ \\
\hline $\mathrm{Ca}^{2+}$, г/л & $\frac{0.016-0.053}{0.029}$ & $\frac{0.009-0.053}{0.027}$ & $\frac{0.019-0.046}{32.1}$ & $\frac{0.001-0.080}{0.020}$ & $\frac{0.001-0.060}{0.020}$ & $\frac{0.003-0.020}{0.008}$ & $\frac{0.001-0.080}{0.010}$ & $\frac{0.005-0.080}{0.050}$ & $\frac{0.006-0.620}{0.100}$ \\
\hline $\mathrm{Mg}^{2+}$, г/л & $\frac{0.004-0.059}{0.015}$ & $\frac{0.004-0.025}{0.010}$ & $\frac{0.015-0.060}{29.9}$ & $\frac{0.001-0.400}{0.070}$ & $\frac{0.003-0.180}{0.060}$ & $\frac{0.050-0.380}{0.210}$ & $\frac{0.001-0.400}{0.050}$ & $\frac{0.030-0.090}{0.060}$ & $\frac{0.010-3.800}{0.620}$ \\
\hline $\mathrm{Na}^{+}$, г/л & $\frac{0.006-0.211}{0.047}$ & $\frac{0.006-0.062}{0.020}$ & $\frac{0.073-0.21}{0.13}$ & $\frac{0.27-125.0}{5.10}$ & $\frac{0.27-19.0}{2.40}$ & $\frac{1.40-17.0}{5.80}$ & $\frac{0.37-125.0}{7.40}$ & $\frac{0.39-5.40}{2.20}$ & $\frac{1.35-65.0}{13.00}$ \\
\hline $\mathrm{K}^{+}$, г/л & $\frac{0.001-0.017}{0.006}$ & $\frac{0.003-0.016}{0.004}$ & $\frac{0.004-0.017}{0.010}$ & 0.060 & $\frac{0.003-0.440}{0.050}$ & $\frac{0.050-0.360}{0.160}$ & $\frac{0.002-0.200}{0.060}$ & $\frac{0.010-0.040}{0.020}$ & $\frac{0.010-0.240}{0.080}$ \\
\hline $\mathrm{Si}$, мг/л & $\frac{0.5-75.0}{2.1}$ & $\frac{0.5-6.0}{2.3}$ & $\frac{0.5-7.5}{2.8}$ & $\frac{2.3-22.0}{5.5}$ & $\frac{3.6-22.0}{6.4}$ & $\frac{4.5-6.8}{5.9}$ & $\frac{2.3-10.0}{4.8}$ & $\frac{2.9-4.1}{3.6}$ & $\frac{3.4-4.5}{3.6}$ \\
\hline $\mathrm{Al}, \mathrm{мкг/л}$ & $\frac{0.008-0.55}{0.058}$ & $\frac{7.8-41.2}{20.0}$ & $\frac{21.4-552}{196}$ & $\frac{0.01-17.0}{0.35}$ & $\frac{0.01-3.50}{0.17}$ & $\frac{0.01-2.10}{0.38}$ & $\frac{0.01-17.0}{0.50}$ & $\frac{0.07-0.40}{0.20}$ & $\frac{0.02-0.42}{0.13}$ \\
\hline REE, мкг/л & $\frac{0.8-5.4}{0.68}$ & $\frac{0.01-0.45}{0.23}$ & $\frac{0.93-5.4}{2.3}$ & $\frac{0.4-109.0}{8.3}$ & $\frac{0.4-56.0}{2.2}$ & $\frac{0.1-109.0}{20.0}$ & $\frac{0.4-82.0}{2.8}$ & $\frac{0.8-1.0}{0.9}$ & $\frac{0.1-2.5}{0.7}$ \\
\hline Zr, мкг/л & $\frac{0.02-0.33}{0.12}$ & $\frac{0.02-0.16}{0.08}$ & $\frac{0.2-0.33}{0.25}$ & $\frac{0.1-1104.0}{50.0}$ & $\frac{0.4-935.0}{50.0}$ & $\frac{0.1-677.0}{115.0}$ & $\frac{0.3-1104.0}{60.0}$ & $\frac{0.7-4.5}{2.0}$ & $\frac{0.1-48.0}{7.8}$ \\
\hline Мо, мкг/л & $\frac{1.87-9.2}{4.8}$ & $\frac{1.87-8.34}{3.94}$ & $\frac{5.30-9.24}{7.46}$ & $\frac{0.003-3.00}{0.12}$ & $\frac{0.003-0.54}{0.06}$ & $\frac{0.013-3.00}{0.78}$ & $\frac{0.01-0.92}{0.09}$ & $\frac{0.02-0.16}{0.07}$ & $\frac{0.02-0.38}{0.09}$ \\
\hline
\end{tabular}

n- количество проб, * min- max/ mean. 


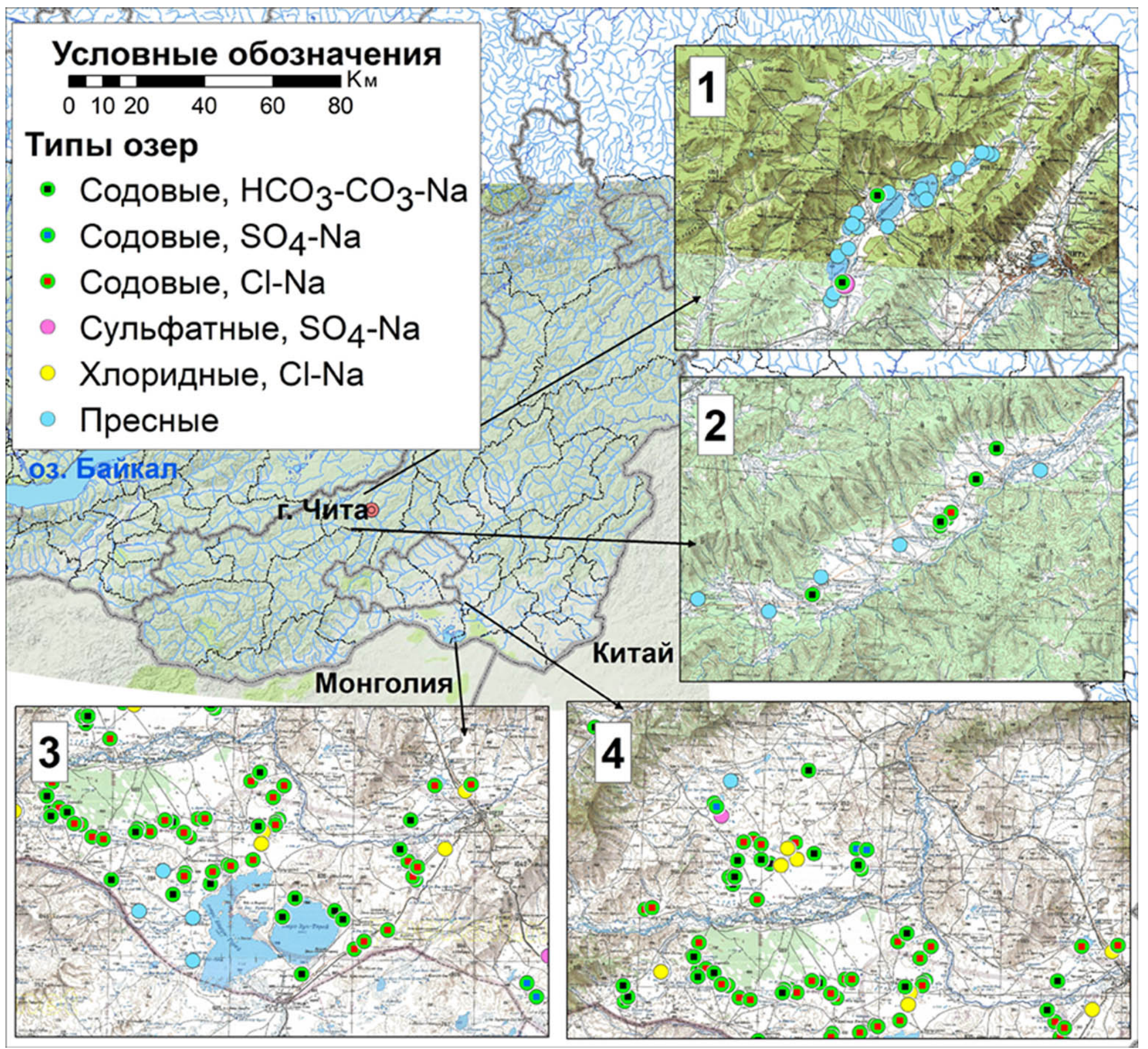



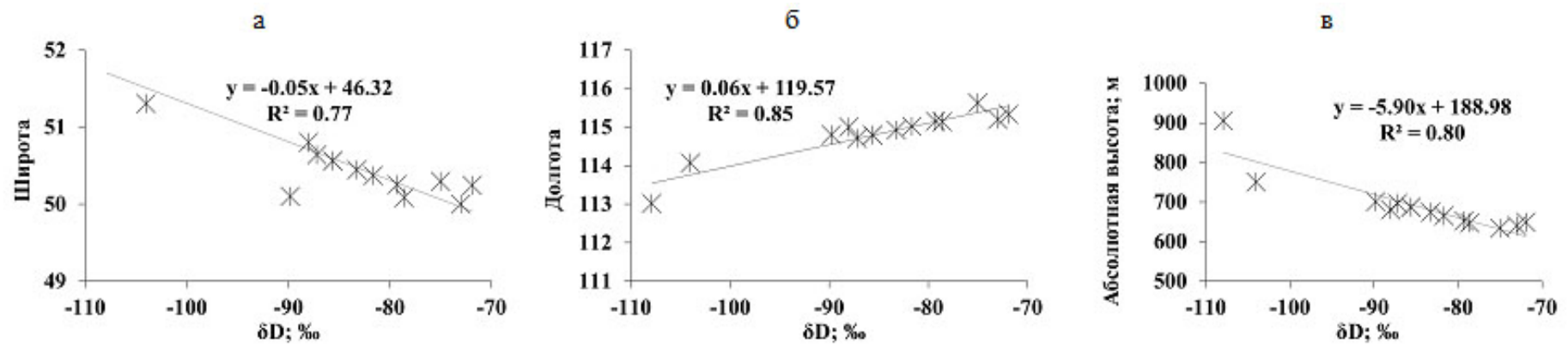
a

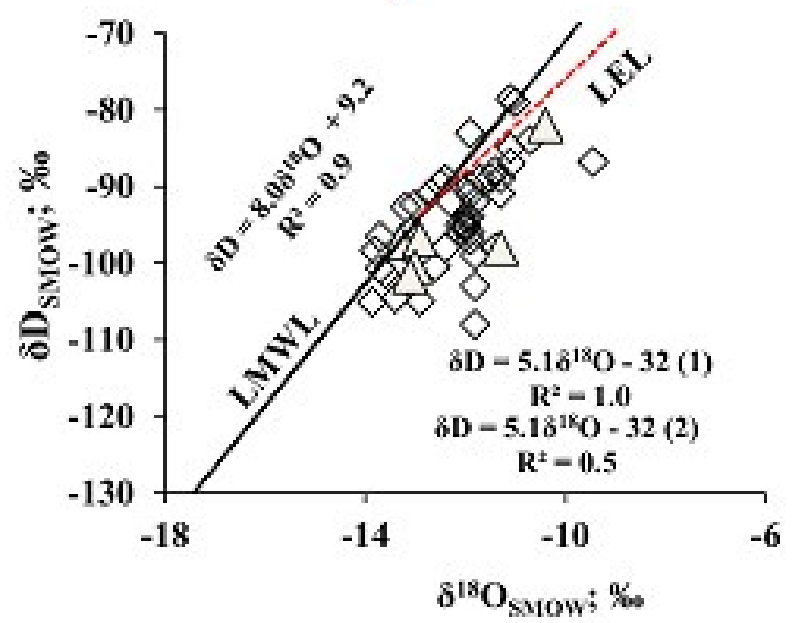

$\diamond$ Подземныс воды (1) $\quad \triangle$ Реки (2)

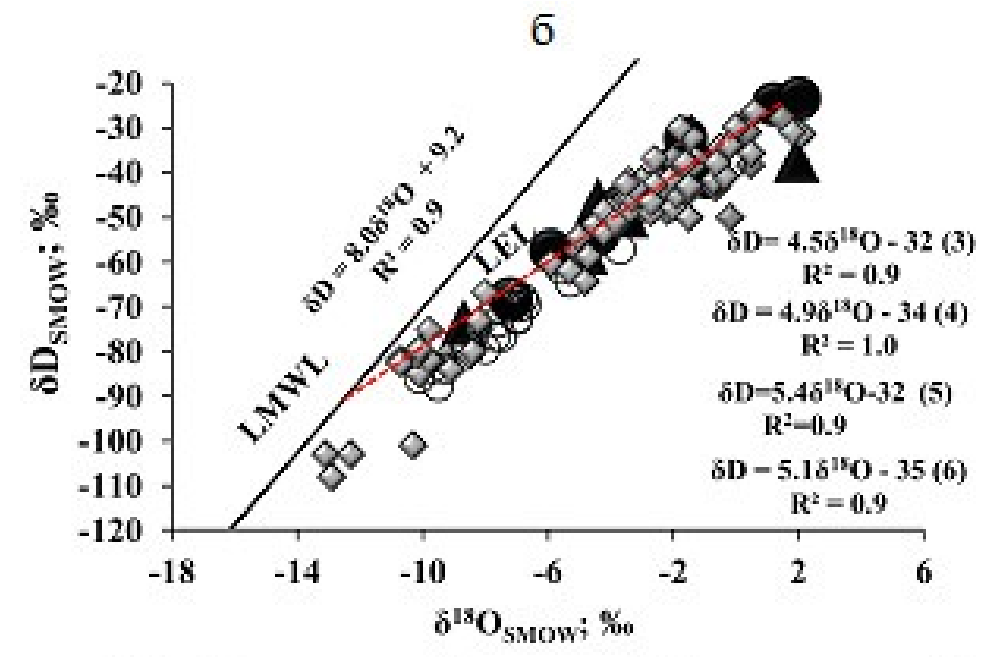

$\Delta$ Сульфатные озера (4) ОПресные озера (6)
- Хлоридные озера (3) $\diamond$ Содовые озера (5) 
a

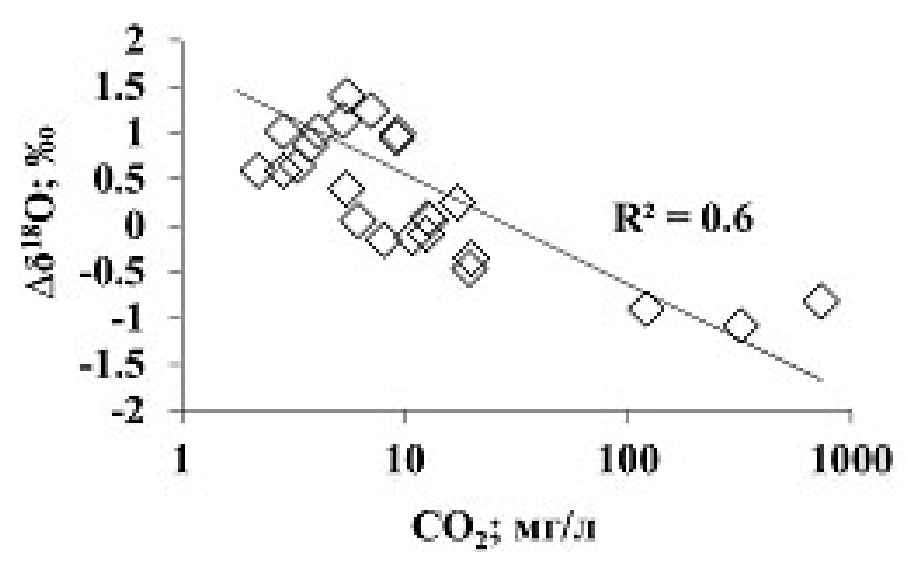

6

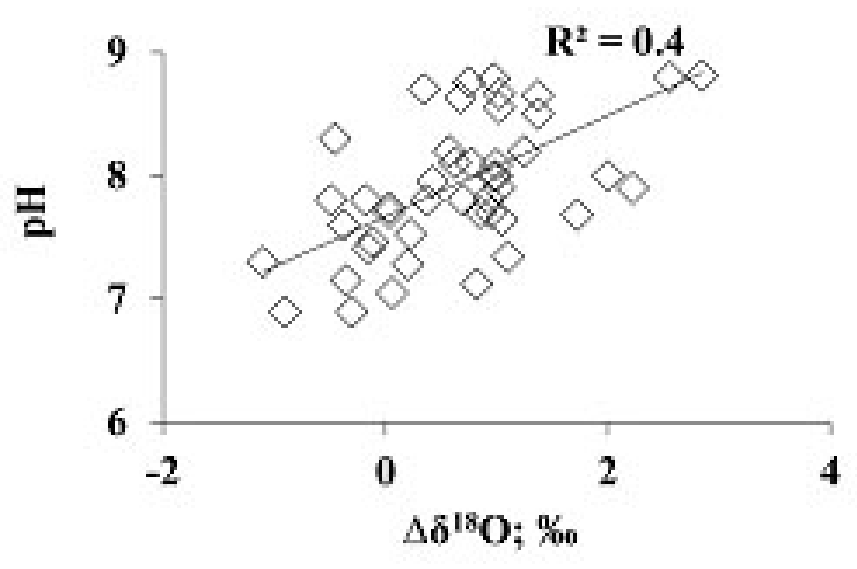


a

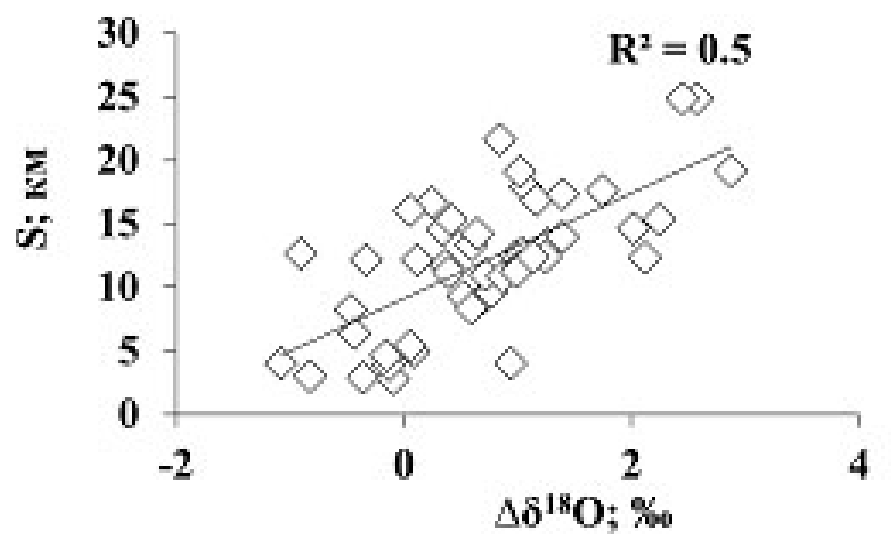

6

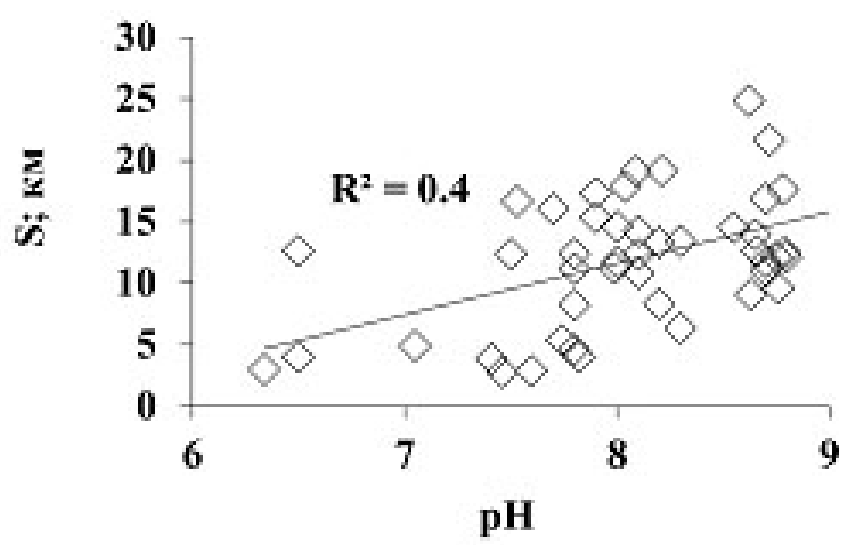




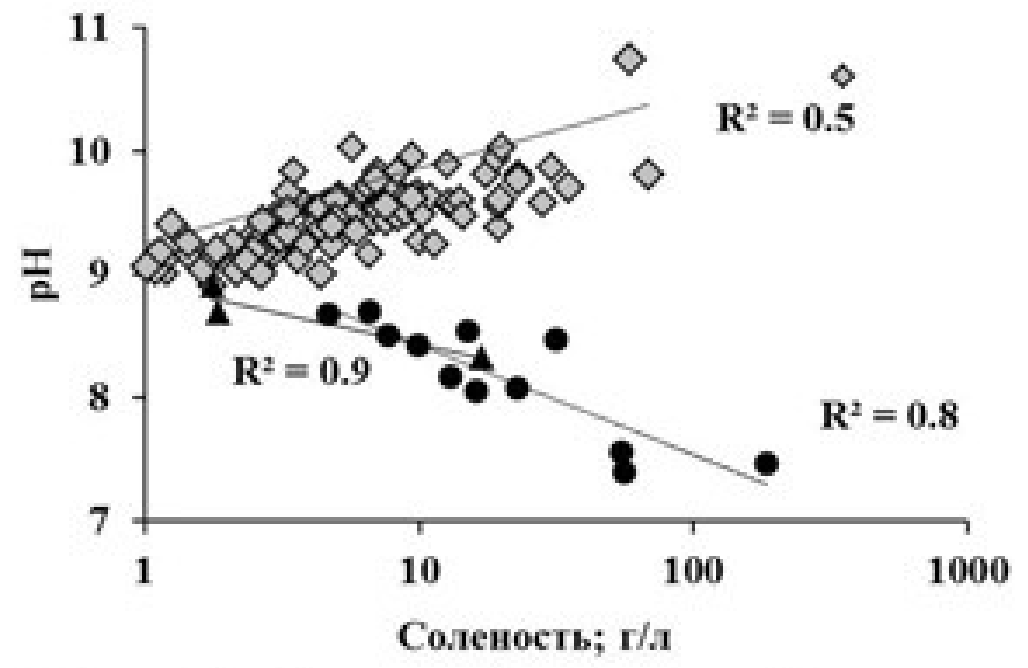

$\diamond$ Содовый $\bullet$ Хлоридшый $\Delta$ Сульфатный типы озер 
a

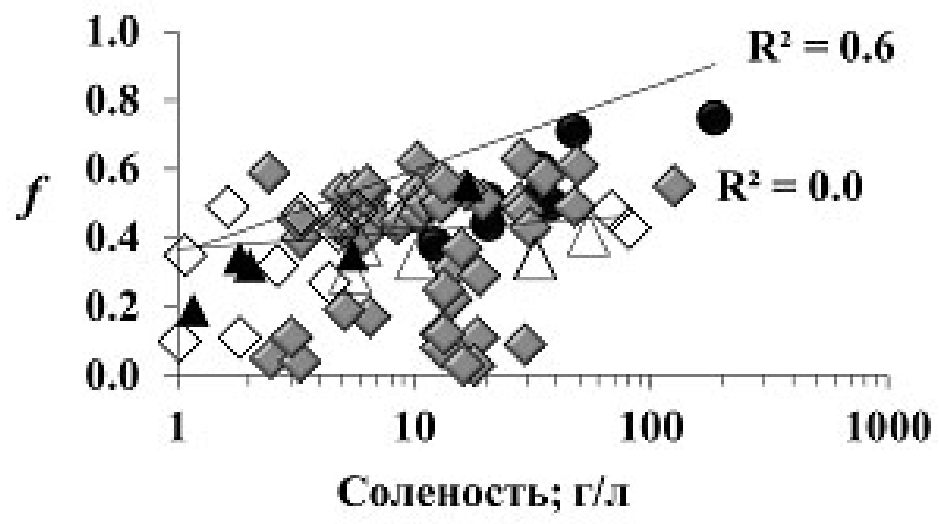

6

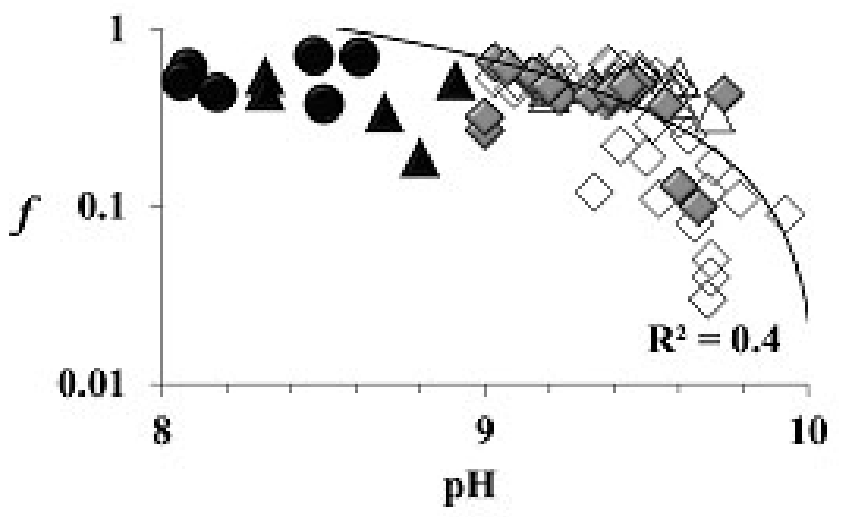

B

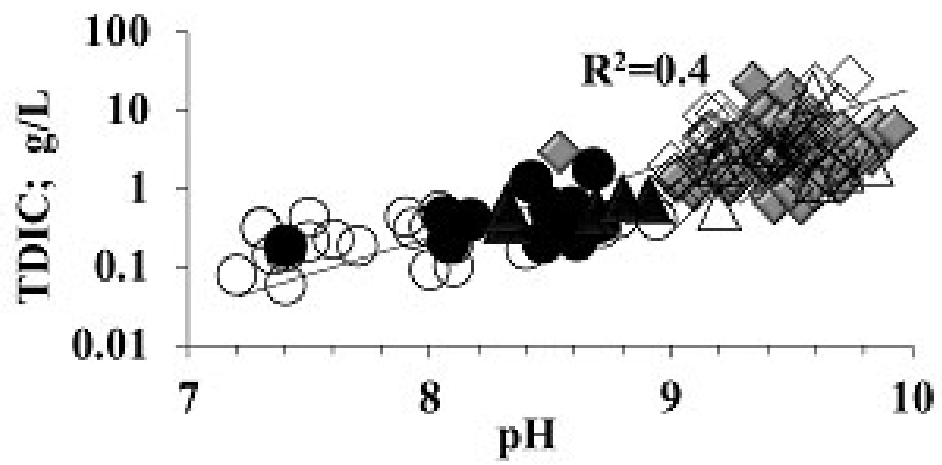

- Хлоридный тип

$\diamond$ Содовый тип III подтип

$\diamond$ Содовый тип I подтип $\triangle$ Сульфатный тип

$\triangle$ Содовый тип II подтип

Пресные озера 


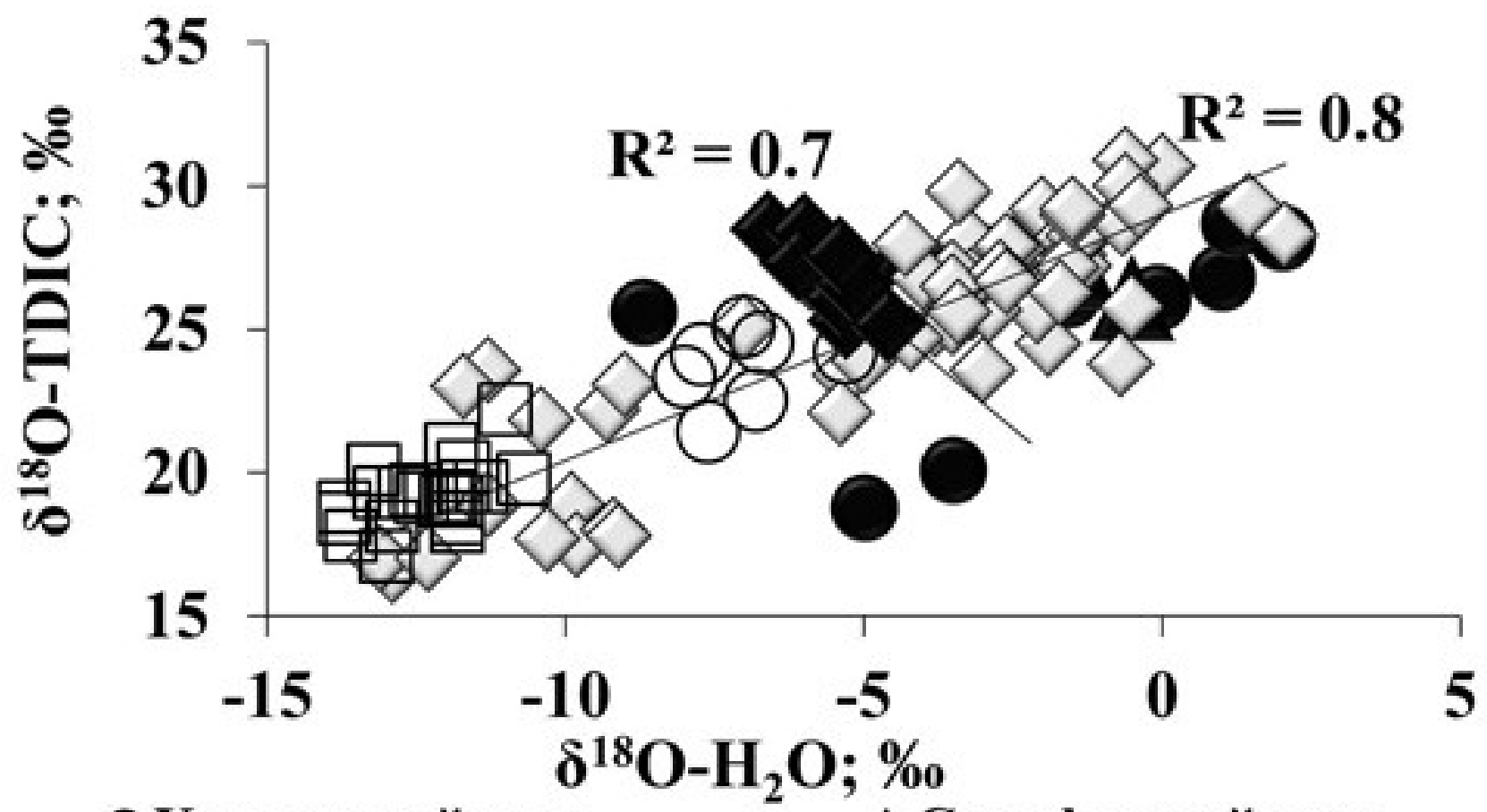

- Хлоридный тип

$\diamond$ Содовый тип

$\square$ Подземные воды

$\Delta$ Сульфатный тип

О Пресные озера

๑ 03. Доронинское 
a

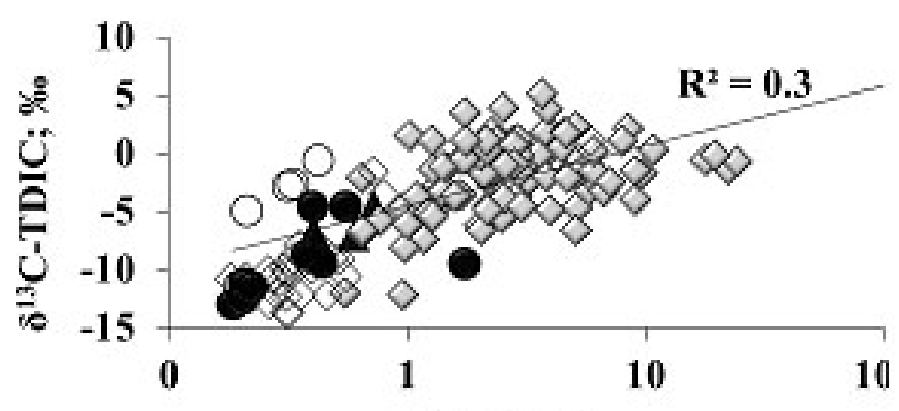

TDIC; $\mathrm{g} / \mathrm{L}$

- Хлоридиые озера

$\diamond$ Содовые озера

ОПресные озера

$$
\begin{aligned}
& \text { А Сульфатиые озера } \\
& \square \text { Подземные воды }
\end{aligned}
$$

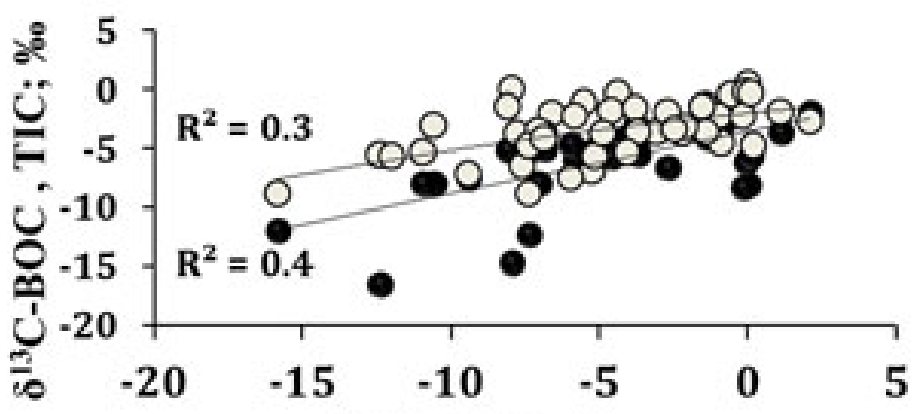
$\delta^{13} \mathrm{C}$-TDIC; \%

- BOC O TIC

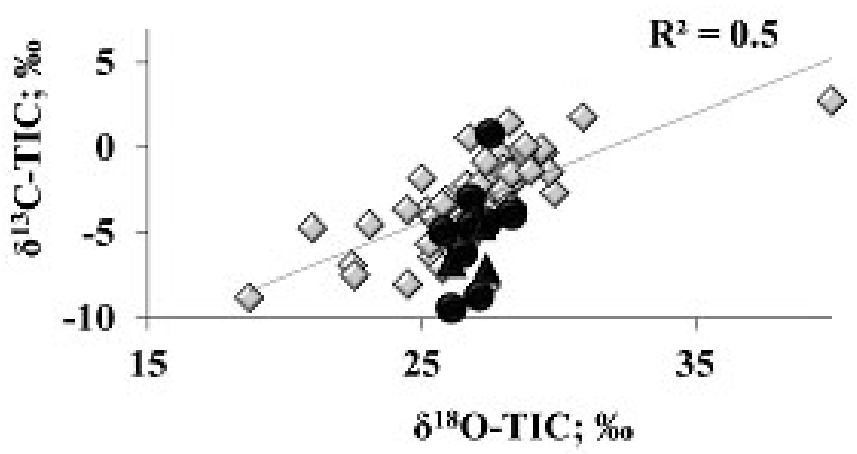

$\diamond$ Содовый 


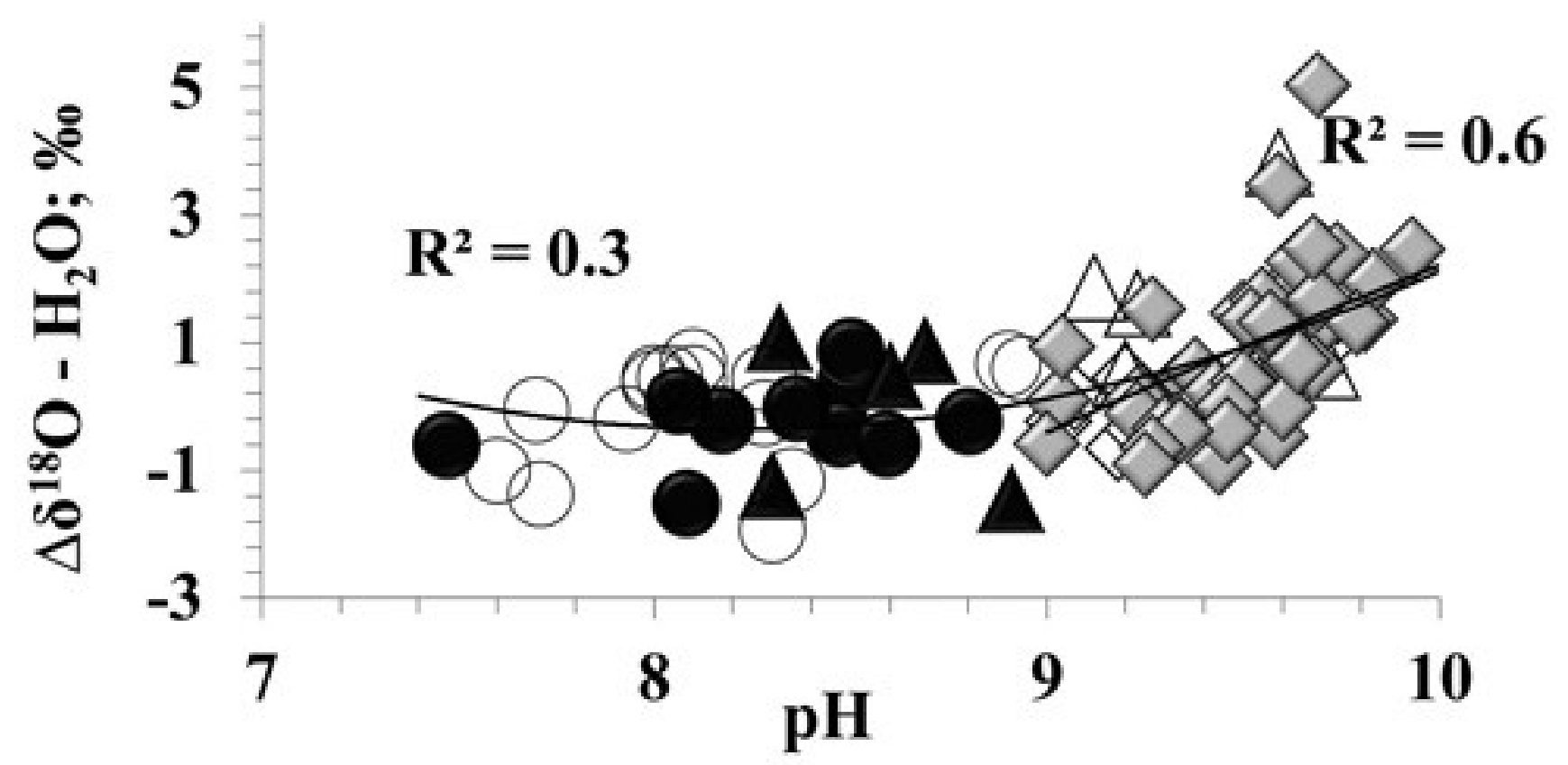

- Хлоридный тип

$\Delta$ Сульфатный тип

Пресные озера

$\diamond$ Содовый тип I подтип

$\triangle$ Содовый тип II подтип

$\diamond$ Содовый тип III подтип 